\title{
Full-scale dynamic tests of a ground support system using high-tensile strength chain-link mesh in El Teniente mine, Chile
}

\author{
R Brändle Geobrugg AG, Switzerland \\ E Rorem Geobrugg North America LLC, USA \\ R Luis Geobrugg AG, Switzerland
}

G Fisher Geobrugg Andina SpA, Chile

\begin{abstract}
Traditional support and reinforcement systems used in underground mining are limited in their capability against dynamic loads. Full-scale dynamic tests carried out by Codelco's El Teniente mine, the largest underground mine in the world, and the Swiss company Geobrugg have shown that the special design, developed by the geotechnical department of this division of Codelco, is highly suitable for protection and support in underground excavations. The design consists of high-tensile steel wire mesh, anchors and shotcrete. Because of the use of high-tensile steel wire (min. 1,770 MPa) and the flexibility of the chain-link mesh, such a support system can be applied in areas with very high static and dynamic stress. The El Teniente mine in Chile is facing significant challenges in terms of seismicity and has to adapt its ground support systems to new high demands in terms of energy absorption and the way the systems are installed inside the tunnels. This innovative ground support system of high-tensile chain-link mesh provides a solution for high energy demands up to $60 \mathrm{~kJ}$. The results achieved thus far, in terms of miners' safety and production performance improvements, are very encouraging.
\end{abstract}

Keywords: dynamic load, rockburst, high-tensile steel wire mesh, ground support, energy absorption

\section{Introduction}

Due to seismicity and the blasting process, rockburst damage is a growing risk in underground excavations around the world. In some locations, the support of tunnels has been achieved with shotcrete reinforced with electro-welded mesh or fibrecrete and friction bolts. This traditional solution was strong and rigid enough to control the movement of small blocks and to avoid the degradation of the rock surface; however, its capacity to absorb impacts and dynamic loads is limited. To deal with rockburst hazards, rockbolts with energy absorption and elongation capacity were used. Even so, a thick application of fibrecrete, shotcrete or cast-in-place concrete with welded mesh reinforcement was required. The development of diamond-shaped lightweight steel wire meshes of very high-tensile strength in recent years has offered alternate design solutions. These 'new' systems when combined with suitable anchors provide alternate design solutions where dynamic ground support loading will occur. This paper relates to 1:1 scale field trials carried out by Codelco in collaboration with Geobrugg. A strong and flexible system was developed which absorbs high energy impacts with reduced deformation. The main goal of the trial was to determine the stress-strain behaviours and maximum energy values achievable under the simulation of repeated dynamic loads of up to $60 \mathrm{kN}$. 


\section{$2 \quad$ High-tensile strength steel wire meshes}

The high-tensile wire $(1,770 \mathrm{MPa})$ mesh offers a surface support for most ground conditions. The mesh is made from high-tensile steel wire with a diameter of 4 and/or $3 \mathrm{~mm}$. The mesh has a specifically developed diamond shape to minimise deformations. Also, along the edges, the wire is looped and twisted back on itself to maintain homogenous strength throughout the entire panel (Figure 1). This enables the edge of the mesh to have the same loading capacity as the mesh (Luis Fonseca et al. 2009). Both mesh types are produced in rolls, which reduces the storage space, and can be manufactured in widths of up to $3.9 \mathrm{~m}$ and in tailor-made lengths corresponding to the tunnel surface to be meshed (i.e. sidewalls and back perimeter). Due to the use of high-tensile wire, the mesh is light in relation to its strength (MINAX ${ }^{\circledR}$ $65 / 4-3.3 \mathrm{~kg} / \mathrm{m}^{2}$, MINAX ${ }^{\circledR} 80 / 4-2.6 \mathrm{~kg} / \mathrm{m}^{2}$ and MINAX ${ }^{\circledR} 80 / 3-1.45 \mathrm{~kg} / \mathrm{m}^{2}$ ). In terms of corrosion protection, the wires are coated with a special aluminium-zinc coating, which has superior corrosion resistance when compared to standard zinc galvanising. Comparison tests based on standardised salt spray tests (Roduner 2012) show that this wire lasts at least three to four times longer under such conditions than conventional zinc galvanised wire.
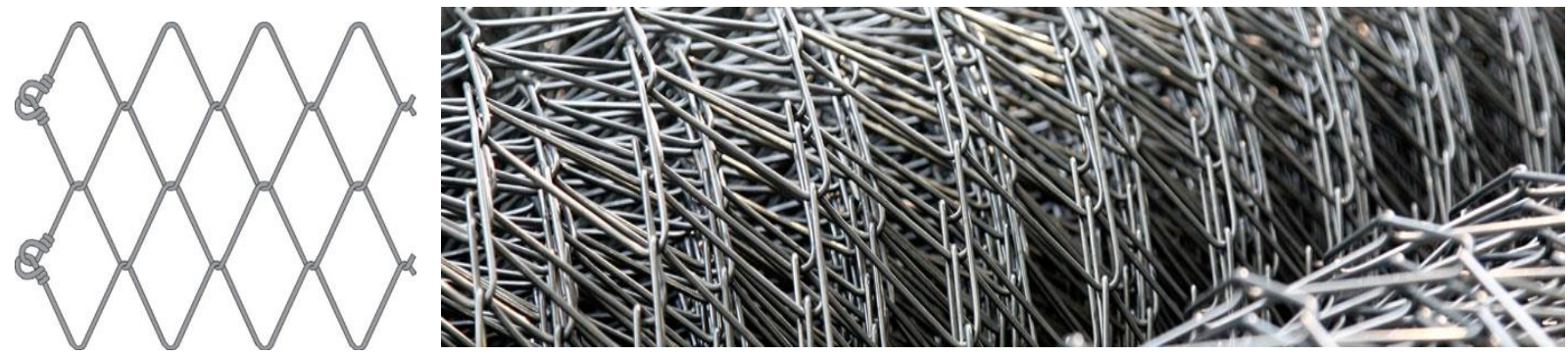

Figure 1 High-tensile steel wire mesh, diamond shaped

The mesh geometry was designed to have a very high breaking load as well as low deformation characteristics to avoid unacceptable deformation rates and unravelling of the rock after a rockburst impact. The resistance properties of the mesh were determined in a series of laboratory tests at the University of Cantabria, Spain (Gutierrez 2002). The properties of the meshes are summarised in Table 1.

Table 1 Properties of the high-tensile mesh

\begin{tabular}{llll}
\hline Material & MINAX $^{\circledR}$ 65/4 & MINAX $^{\circledR} 80 / 4$ & MINAX $^{\circledR} 80 / 3$ \\
\hline Mesh width & $63 \mathrm{~mm}$ & $80 \mathrm{~mm}$ & $80 \mathrm{~mm}$ \\
Diagonal & $83 \times 138 \mathrm{~mm}$ & $102 \times 177 \mathrm{~mm}$ & $103 \times 180 \mathrm{~mm}$ \\
Wire diameter & $4 \mathrm{~mm}$ & $4 \mathrm{~mm}$ & $3 \mathrm{~mm}$ \\
Wire strength & $1,770 \mathrm{MPa}$ & $1,770 \mathrm{MPa}$ & $1,770 \mathrm{MPa}$ \\
Breaking load - single wire & $22 \mathrm{kN}$ & $22 \mathrm{kN}$ & $12.5 \mathrm{kN}$ \\
Tensile strength & $250 \mathrm{kN} / \mathrm{m}$ & $190 \mathrm{kN} / \mathrm{m}$ & $110 \mathrm{kN} / \mathrm{m}$ \\
Weight & $3.3 \mathrm{~kg} / \mathrm{m}^{2}$ & $2.6 \mathrm{~kg} / \mathrm{m}^{2}$ & $1.45 \mathrm{~kg} / \mathrm{m}^{2}$ \\
\hline
\end{tabular}

\section{$3 \quad$ High-tensile strength chain-link mesh in El Teniente mine, Chile}

The technical management of Codelco in the El Teniente mine chose, to use as a surface support system, a combination of elements to generate a surface support system (Fischer 2016). In this case, the surface support system used was applied in two steps (Figure 2(b)). The first layer consists of $70 \mathrm{~mm}$ shotcrete including high-tensile diamond mesh type MINAX ${ }^{\circledR} 80 / 4$ applied over the top, anchored with solid $\phi 25 \mathrm{~mm}$ 
bolts. The second layer consists of a thin layer $(30 \mathrm{~mm}$ ) of shotcrete to encase the mesh with high-tensile diamond mesh type MINAX ${ }^{\circledR} 65 / 4$ installed over the top, anchored with cable bolts (seven strands) up to $4 \mathrm{~m}$ long, arranged radially, as shown in Figure 2(a). This combined solution is intended for ground support under dynamic load conditions due to seismic accelerations which have occurred in the areas under design and have caused the collapse of a complete tunnel in the El Teniente mine. In March 2016, an event of magnitude 1.2 and a total energy of $4 \times 10^{5} \mathrm{~J}$ occurred, with important consequences from the point of view of safety and production security (Muñoz 2017). Therefore, it had to be validated whether the estimated properties for the design of the combined system could withstand dynamic impacts of up to $60 \mathrm{~kJ}$. For this purpose, a testing facility was designed to simulate rockburst dissipation energy and to evaluate the transmission of loads to the anchors. Dynamic laboratory tests and large-scale tests are reviewed in this paper.

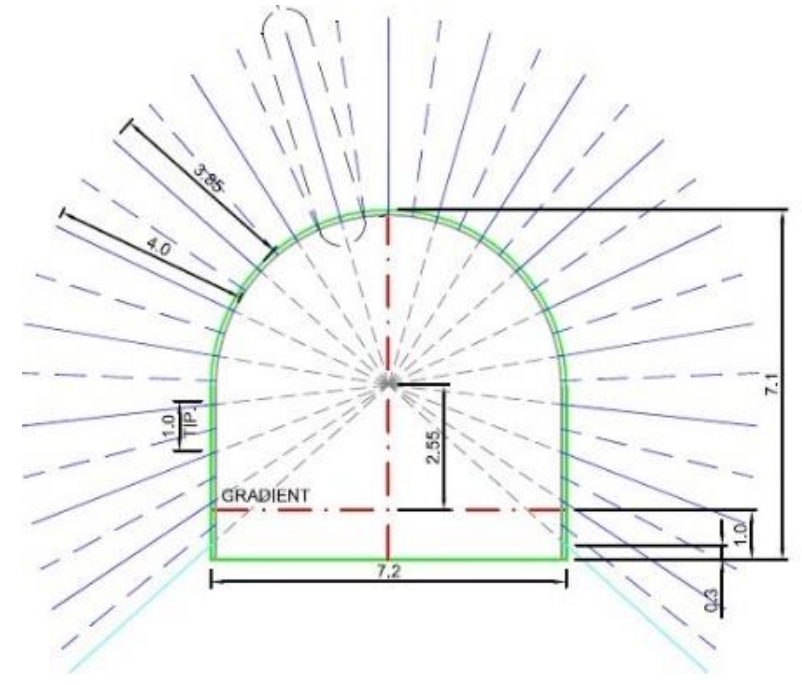

(a)

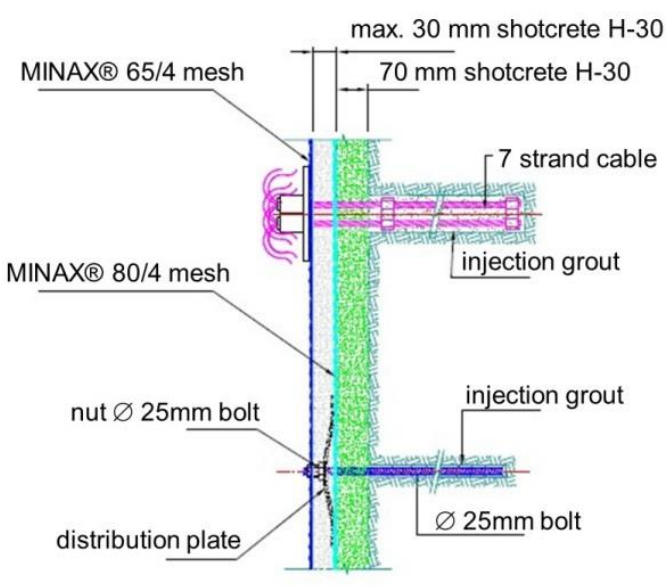

(b)

Figure 2 Surface support system used in El Teniente mine (Muñoz 2017)

\section{Dynamic laboratory tests}

The MINAX ${ }^{\circledR} 80 / 4$ mesh was tested at the dynamic testing facility of the Western Australia School of Mines (WASM) (Player et al. 2008) by using a momentum transfer method (Player et al. 2004; Thompson et al. 2004; Roth et al. 2004). The mesh panel is installed using shackles and eye bolts in the frame and the weight is placed on top of the mesh. The full system is dropped onto buffers from different heights. When the system hits the buffers, everything comes to a sudden stop, except the weight placed on the mesh, which keeps decelerating and loading the mesh dynamically (Morton et al. 2007). This test simulates the actual underground conditions with the mesh placed onto the rock mass, which can be ejected into the surface support (mesh) under dynamic load. The dynamic test apparatus is instrumented with a high-speed video camera, load cells and accelerometers. Figure 3 shows a general view of the test setup at the WASM facility (Roth 2013). 


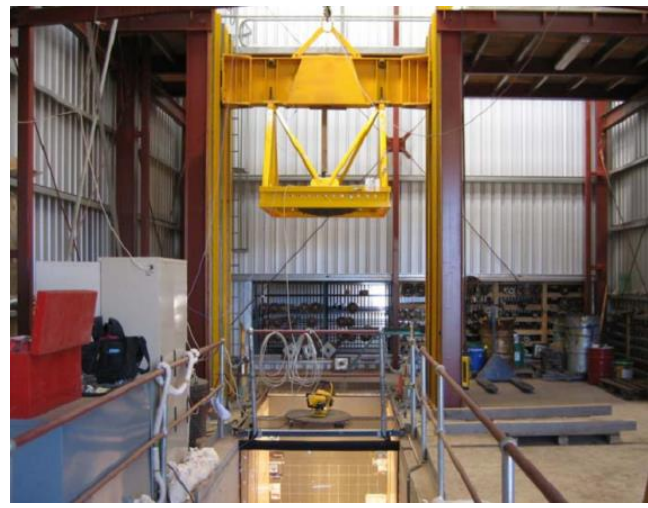

Figure 3 Dynamic test set-up at the Western Australian School of Mines, Kalgoorlie (Roth 2013)

Figure 4 shows images from a camera (Figure 4(a)) and a high-speed video camera (Figure 4(b)) before and after a mass of 1,000 kg (a bag filled with mill steel balls) loads the high-tensile chain-link mesh. The mesh deforms with the applied load and transfers the forces to the boundary. The boundary conditions are fixed in the interest of ensuring comparable and repeatable results.

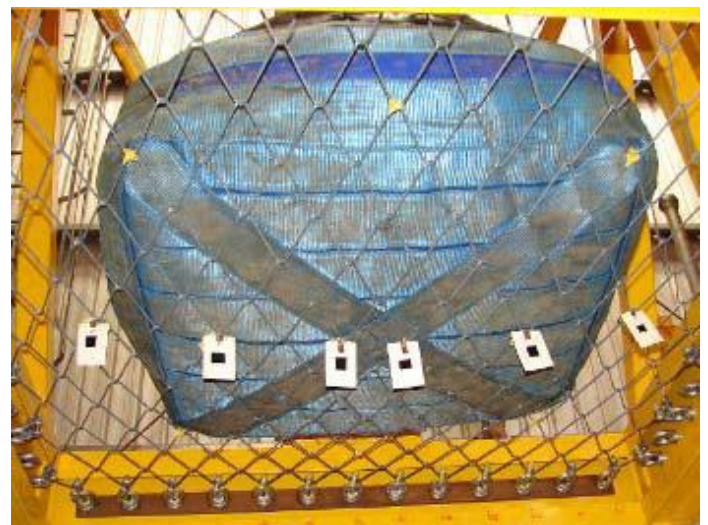

(a)

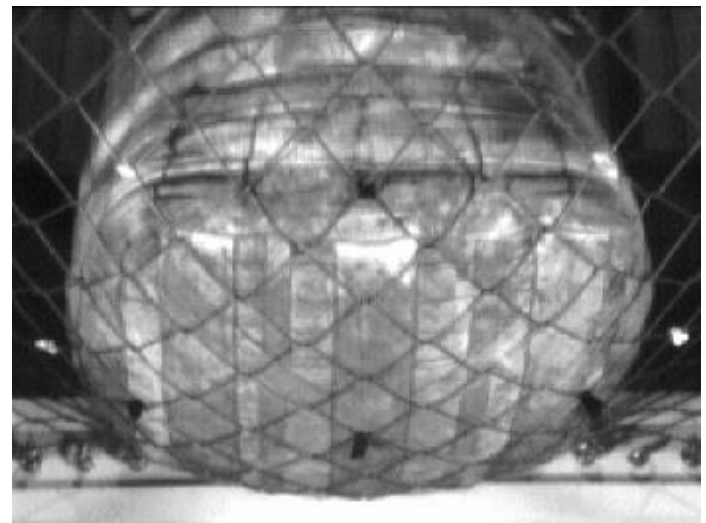

(b)

Figure 4 Photo (a) Looking up to the test set-up before the 1,000 kg impact mass; and, (b) From the high-speed video camera after impact

These tests established that the high-tensile chain-link mesh MINAX ${ }^{\circledR} 80 / 4$ is able to absorb energies up to $12 \mathrm{~kJ}$ in such a configuration (Villaescusa et al. 2012). This is equal to stopping a rock mass of $1,000 \mathrm{~kg}$ that is accelerated to $4.9 \mathrm{~m} . \mathrm{s}^{-1}$. This value represents the energy absorption of the mesh only and does not include any absorption by the rock mass or the yielding bolts. Welded wire mesh $(5.6 \mathrm{~mm}, 100 \times 100 \mathrm{~mm})$ showed energy absorption capacities up to only $2 \mathrm{~kJ}$ in the same test configuration.

In order to determine the distribution of loads between the anchor bolts and the surface support, tests were carried out at the Geobrugg test facility in Switzerland (Bucher et al. 2013). It was found from the tests results that load distribution between bolts depends on rock mass stiffness. That is, for a strong, massive rock mass, $25 \%$ of the dynamic energy entering the system is absorbed by the mesh, whereas the remaining $75 \%$ is absorbed by the rockbolts. On the other hand, for a weak, blocky rock mass, $70 \%$ of the energy is absorbed by the mesh and $30 \%$ by the bolts. These cases stand for both extreme conditions; therefore, a 50/50 load distribution could reasonably be expected to fit most cases. For a conservative design, a $70 \%$ energy absorption by the mesh could be chosen. 


\section{$5 \quad$ Codelco large-scale rockburst test}

The large-scale testing of the surface support system was the main part of a research and development project supported by Codelco. These tests were conducted in September 2016 in a quarry and rockfall testing facility in Walenstadt, Switzerland. The test report prepared by the Dynamic Test Center AG (DTC) (Saner \& Murri 2016) summarises this work. These tests aim to increase knowledge about the behaviour and the interaction between the ground and the anchored flexible support (in case of dynamic loads). Moreover, the reliability of the dimensioning hypothesis, based on test site observations and back calculations, were to be verified.

Initial results allowed optimisation of the testing facility and procedure as well as the data acquisition methodology. Further tests were conducted to ensure reliable and comparable experimental results.

The rockburst energy is simulated by dropping a barrel filled with steel and concrete into the middle of a shotcrete panel. Accelerations of the three main axes were recorded on top of the barrel and the forces acting on the anchors were measured as well. Two high-speed and two real-time cameras recorded the testing. The deflection was determined from data analysis of the high-speed camera.

\section{$5.1 \quad$ Testing set-up}

The test device has a shape of a pyramid with a square base (Figure 5(a)). It is composed of a platform with a two-level table. The upper level is housing the impact set corresponding to a 1,320 kg barrel. This barrel is dropped from a height of $4.6 \mathrm{~m}$ (tests S3 and S5) and $2.3 \mathrm{~m}$ (test S4). The barrel is guided by four steel profiles. The lower level is composed of a composite shotcrete slab and mesh layers fixed by anchors, with the anchors fixed to the selves upper level. The impact area was increased to $1 \mathrm{~m}^{2}$ by a steel plate (Figure 5(b)). A copper contact was mounted on the steel plate to determine the moment of first impact.

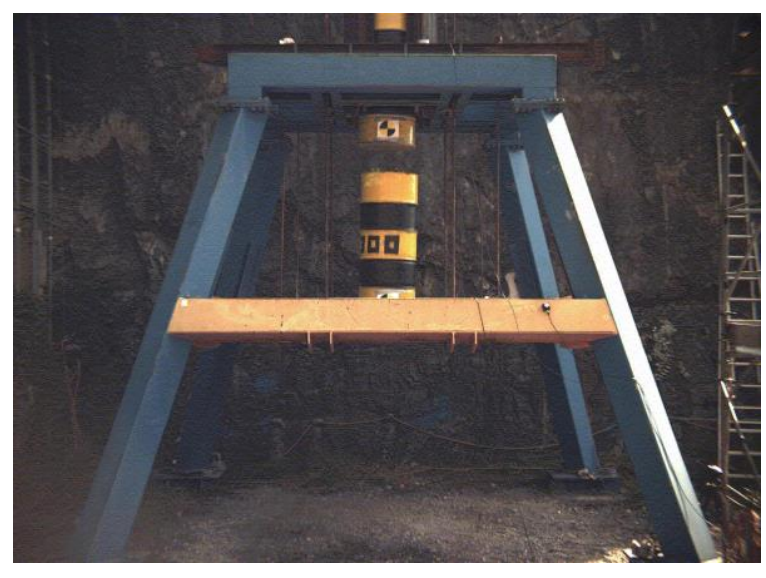

(a)

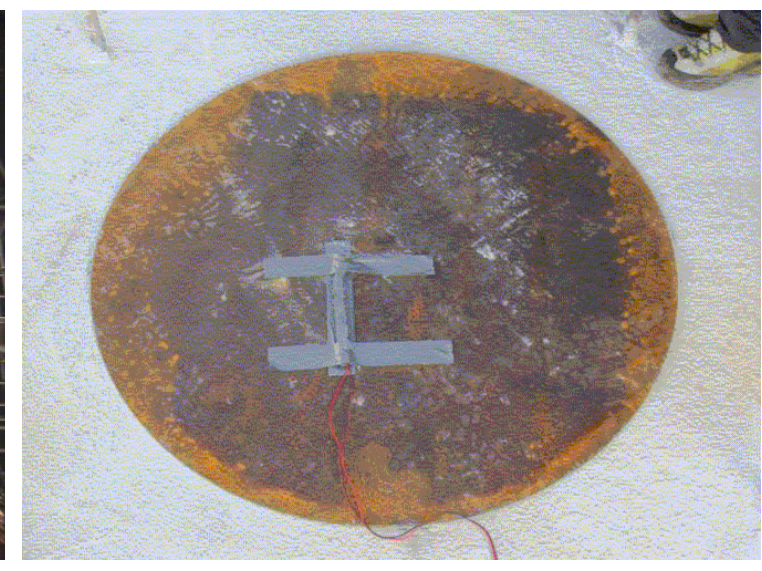

(b)

Figure 5 Photo of the (a) Frontal view of the full set-up; and, (b) Steel plate on shotcrete floor with the trigger contact of impact

Figure 6 illustrates the lower level slab with dimensions of $3.6 \times 3.6 \mathrm{~m}$. Two anchoring layers simulate the ground support. The outer layer composed of cable bolts of $140 \mathrm{~mm}^{2}$ are arranged in a grid of $2.0 \times 2.0 \mathrm{~m}$. The inner layer is arranged in a $1.2 \times 1.2 \mathrm{~m}$ grid with anchors of $\phi 25 \mathrm{~mm}$ in diameter. 


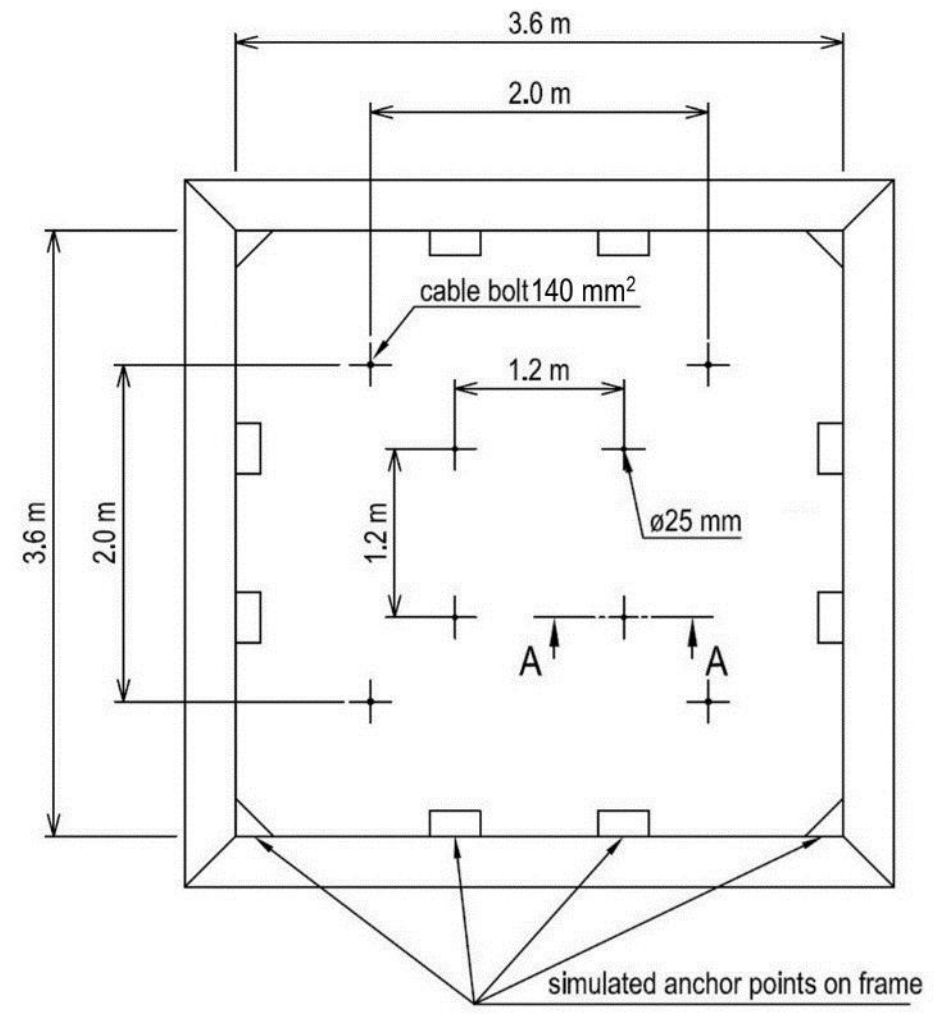

Figure 6 Lower level frame top view with the shotcrete slab and the anchoring points

The previously described composite shotcrete slab is in itself composed of two layers. The upper one is approximately $70 \mathrm{~mm}$ thick and consists of shotcrete, with a layer of high-tensile strength mesh type MINAX ${ }^{\circledR} 65 / 4$ placed underneath. The lower shotcrete layer is thinner ( $30 \mathrm{~mm}$ ) with a second mesh layer type MINAX ${ }^{\circledast} 80 / 4$ below it (see details in Figure 7).

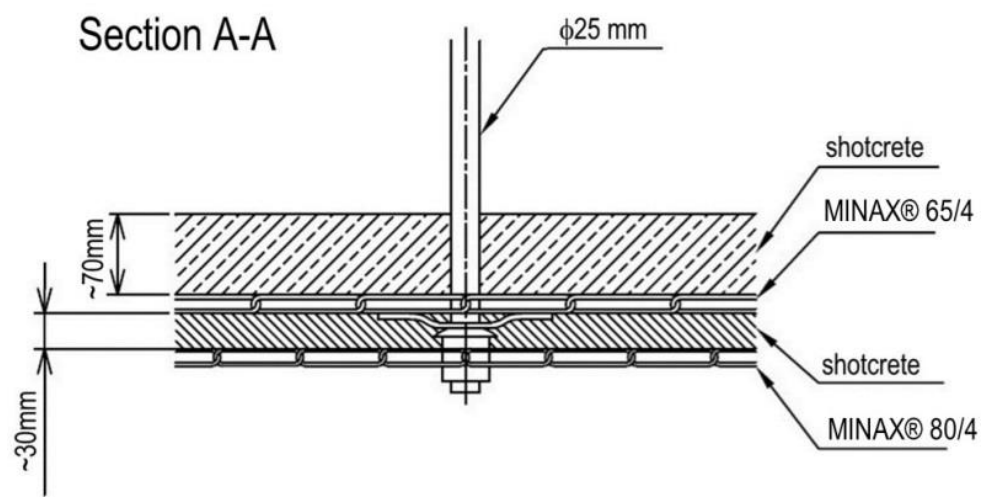

Figure 7 Cross-section A-A composed of two layers of shotcrete and two of high-tensile strength mesh

\subsection{Measurement and data recording}

The accelerations of the barrel were measured using a three-axis accelerometer $(2,000 \mathrm{~g})$. In-dummy measuring technology was used, with the sensors storing the data (Figure 8(a)). The recording is continuous even through cable interruptions. At the end of testing, the data can then be downloaded when reconnected to the gateway. The forces were measured with four load cells in four anchors. Due to the symmetrical design, the measured forces were multiplied by two for the resultant force on all eight anchors. Measurement channels 1, 2, 3 and 4 correspond to the anchors (Figure 8(b)). 


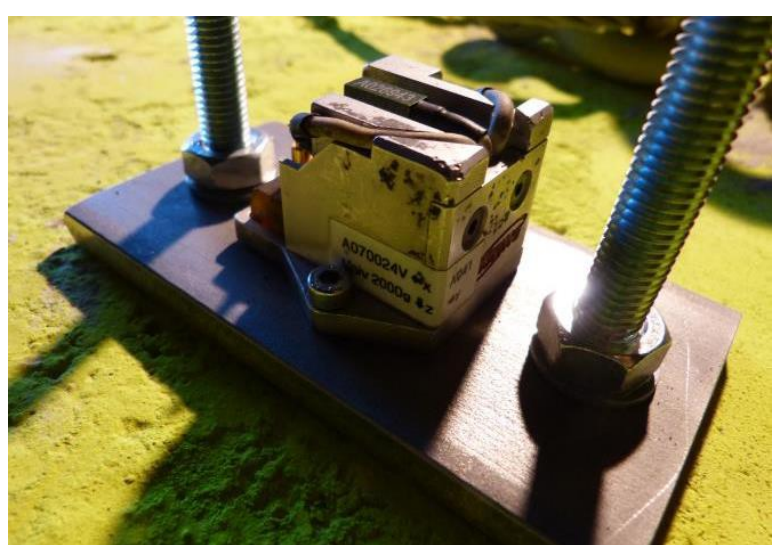

(a)

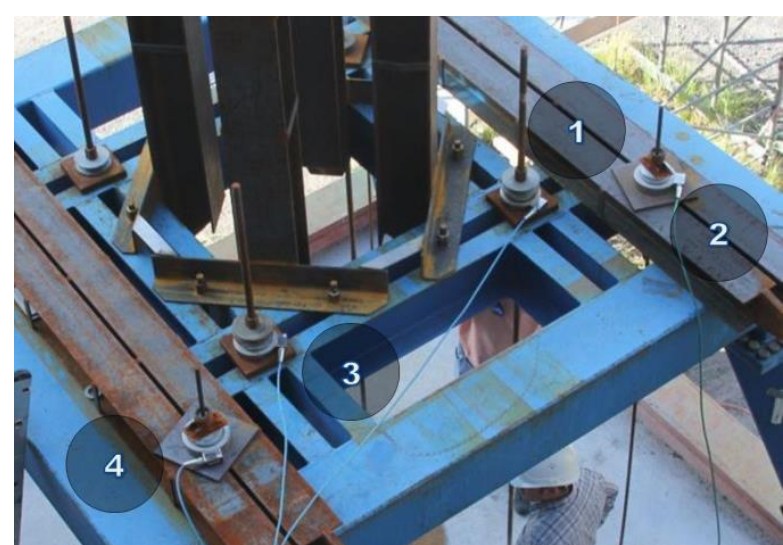

(b)

Figure 8 (a) Measuring equipment on top of the barrel; and, (b) Load measurement cells

The origin of the coordinates system is in the middle of the shotcrete floor where the barrel hits the metal plate: $+X$ (positive right), $+Y$ (positive back) and $+Z$ (positive upwards) (Figure 9). The measurements of the stresses are obtained by using the accelerometers placed in the barrel. These give measurements on the axes of coordinates previously described and the forces in the anchors from the load cells (Figure 8(b) and Table 2). The measurement equipment was triggered manually.

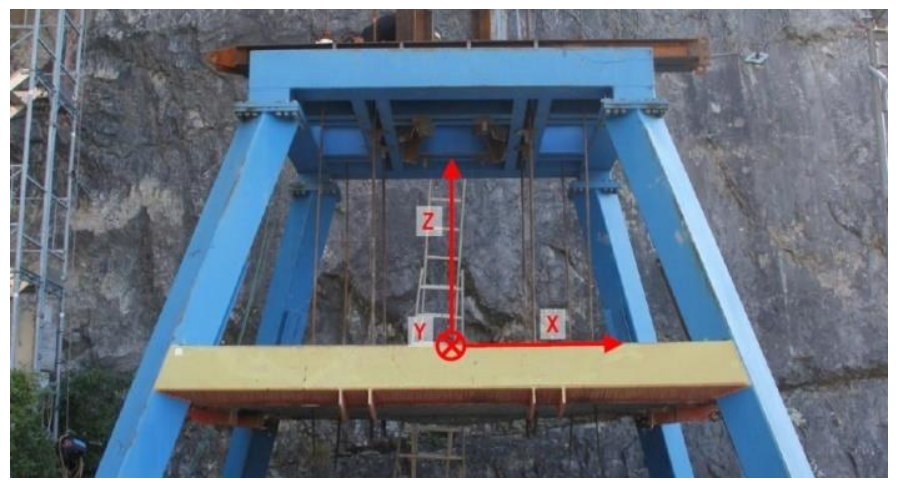

Figure 9 Test field coordinate system

Table 2 Summary of the measuring points

\begin{tabular}{lllll}
\hline Measuring point & Size/type sensor & Frequency & Direction & Video camera filter \\
\hline $\begin{array}{l}\text { Barrel } \\
\text { accelerations }\end{array}$ & $\begin{array}{l}\text { 2,000 g triaxial } \\
\text { accelerometer }\end{array}$ & $20 \mathrm{kHz}$ & $\mathrm{x}, \mathrm{y}, \mathrm{z}$ & CFC 180 \\
Anchor 1 & $500 \mathrm{kN}$ & $4.8 \mathrm{kHz}$ & Pulling direction & CFC 180 \\
Anchor 2 & $500 \mathrm{kN}$ & $4.8 \mathrm{kHz}$ & Pulling direction & CFC 180 \\
Anchor 3 & $500 \mathrm{kN}$ & $4.8 \mathrm{kHz}$ & Pulling direction & CFC 180 \\
Anchor 4 & $500 \mathrm{kN}$ & $4.8 \mathrm{kHz}$ & Pulling direction & CFC 180 \\
\hline
\end{tabular}

Note: CFC is the abbreviation for channel frequency class.

Two stationary digital high-speed cameras and two real-time cameras were used for the visual documentation of the test and for the determination of deflection. The cameras were manually triggered and synchronised by LEDs. For the frontal view, the AOS Technologies Extended Environmental Application (X-EMA) high-speed camera (AOS Technologies AG 2017a) is used under the toughest conditions (Figure 10(a)). The main features are 1,280 $\times 1,024$ resolution up to $500 \mathrm{fps}$, rechargeable battery built in for true mobile applications and data backup, image memory built-in (DRAM), Gigabit Ethernet interface 
and auto exposure control. The AOS X-PRI high-speed camera (AOS technologies AG 2017b) includes features such as built-in battery, stand-alone operation, $800 \times 600$ pixel sensor, and Gigabit Ethernet date interface and one status input line to integrate external status signals (Figure 10(b)).

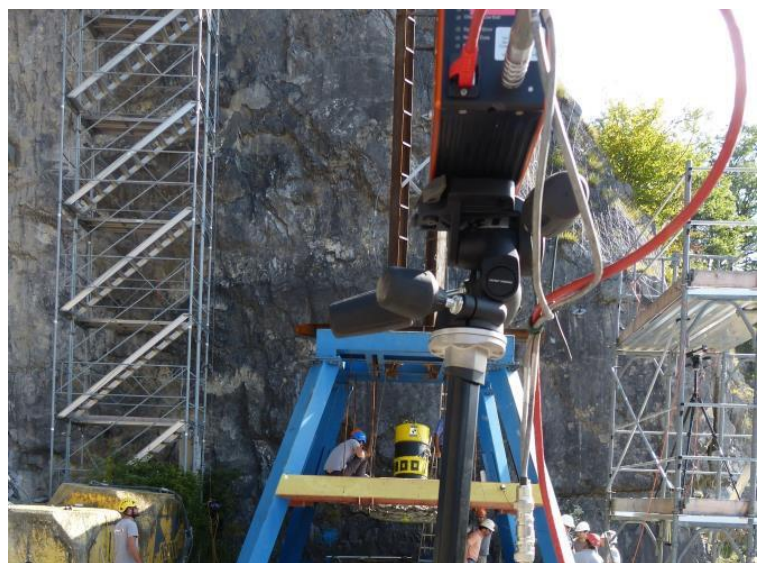

(a)

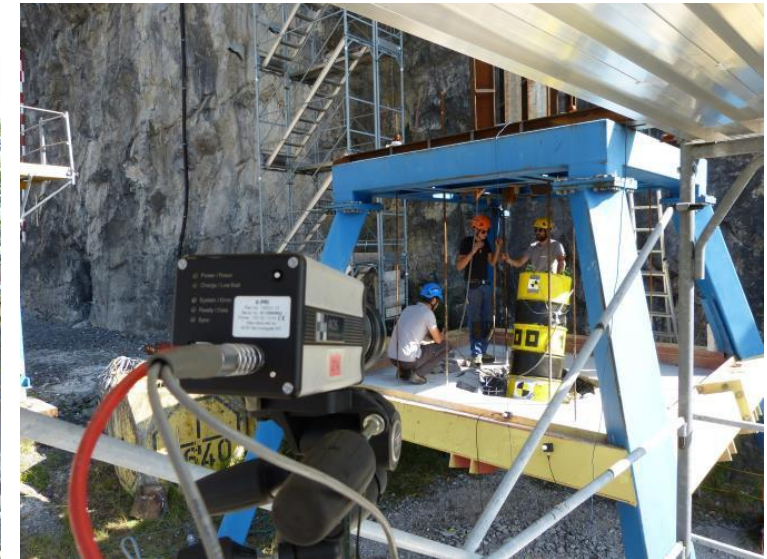

(b)

Figure 10 (a) Camera AOS X-EMA focal distance $25 \mathrm{~mm}$; and, (b) Camera AOS X-PRA focal distance $50 \mathrm{~mm}$

\subsection{Test results and video analysis}

On 28 September 2016, three trials were executed; S3, S4 and S5. In all tests, the same barrel was used in the same impact area $\left(1 \mathrm{~m}^{2}\right.$ ), while the release height was varied from $4.60 \mathrm{~m}$ (S3 and S5) to $2.30 \mathrm{~m}$ in the S4 test, which halved the energy at contact. A sequence of frames is shown in Figure 11 during the first test (S3). In this sequence, it was possible to see the effect of the impact of the barrel on the distribution plate of $1 \mathrm{~m}^{2}$ on the shotcrete slab and the rebound effect manifested once it reaches the maximum deflection at $\mathrm{t}=75 \mathrm{~ms}$ (Figure 14).

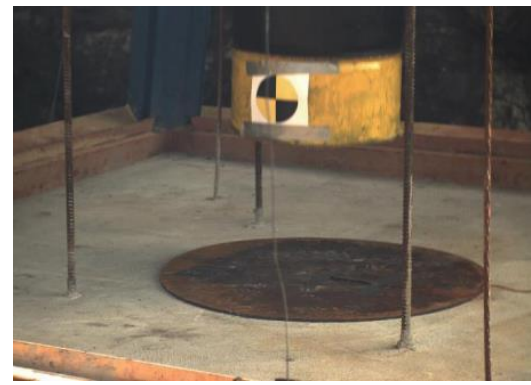

$\mathrm{t}=-50 \mathrm{~ms}$

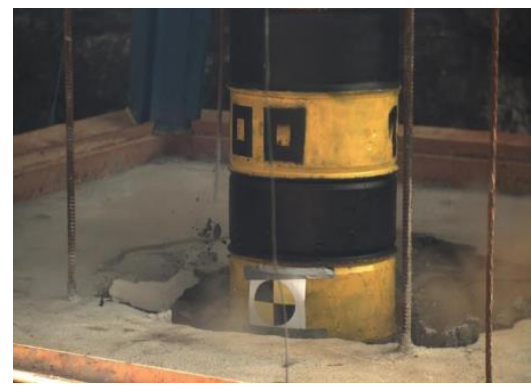

$\mathrm{t}=100 \mathrm{~ms}$

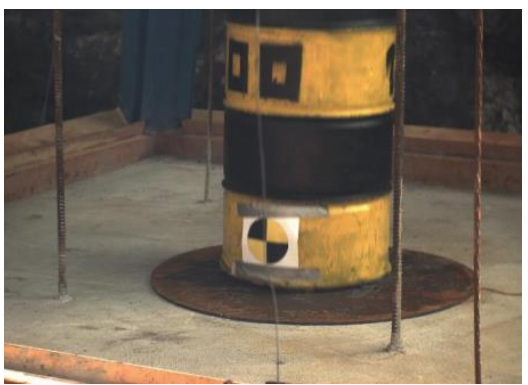

$\mathrm{t}=0 \mathrm{~ms}$

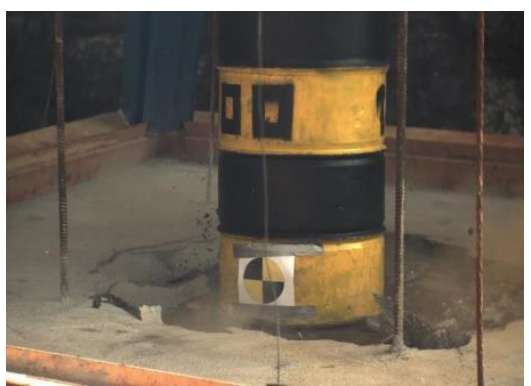

$\mathrm{t}=150 \mathrm{~ms}$

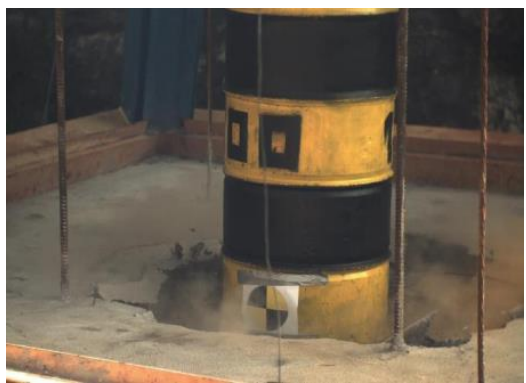

$\mathrm{t}=50 \mathrm{~ms}$

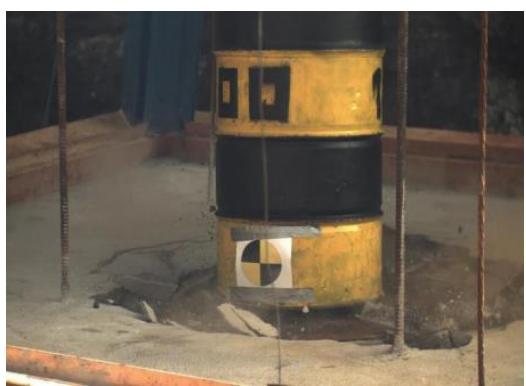

$\mathrm{t}=200 \mathrm{~ms}$

Figure 11 Impact sequence during test S3, with rebound from $100 \mathrm{~ms}$ 
The S3 test results are shown in Figures 12 to 14 and Table 3. The release height was $4.60 \mathrm{~m}$ (that means a speed of $9.5 \mathrm{~m} / \mathrm{s}$ ) and the barrel weighs $1,320 \mathrm{~kg}$, which corresponds to an impact energy of $60 \mathrm{~kJ}$ (Figure 12). In this case, the total amount of force transferred into the anchoring system is $429 \mathrm{kN}$ and the maximum deceleration achieved was $70.5 \mathrm{~g}$ (Figure 13). The barrel was completely restrained by the rockburst support set-up with a central deflection of $0.24 \mathrm{~m}$, and a corresponding static deflection value slightly lower at $0.225 \mathrm{~m}$ (Figure 14). No permanent deformation was observed on the inner rockbolts.

\section{Table 3 Summary S3 test results}

\begin{tabular}{ll}
\hline Drop height & $4.60 \mathrm{~m}$ \\
Impact energy & $60 \mathrm{~kJ}$ \\
Max. anchor reaction & $429 \mathrm{kN}$ \\
Max. deceleration & $70.5 \mathrm{~g}$ \\
Max. central deflection & $0.24 \mathrm{~m}$ \\
Static deflection & $0.225 \mathrm{~m}$ \\
\hline
\end{tabular}

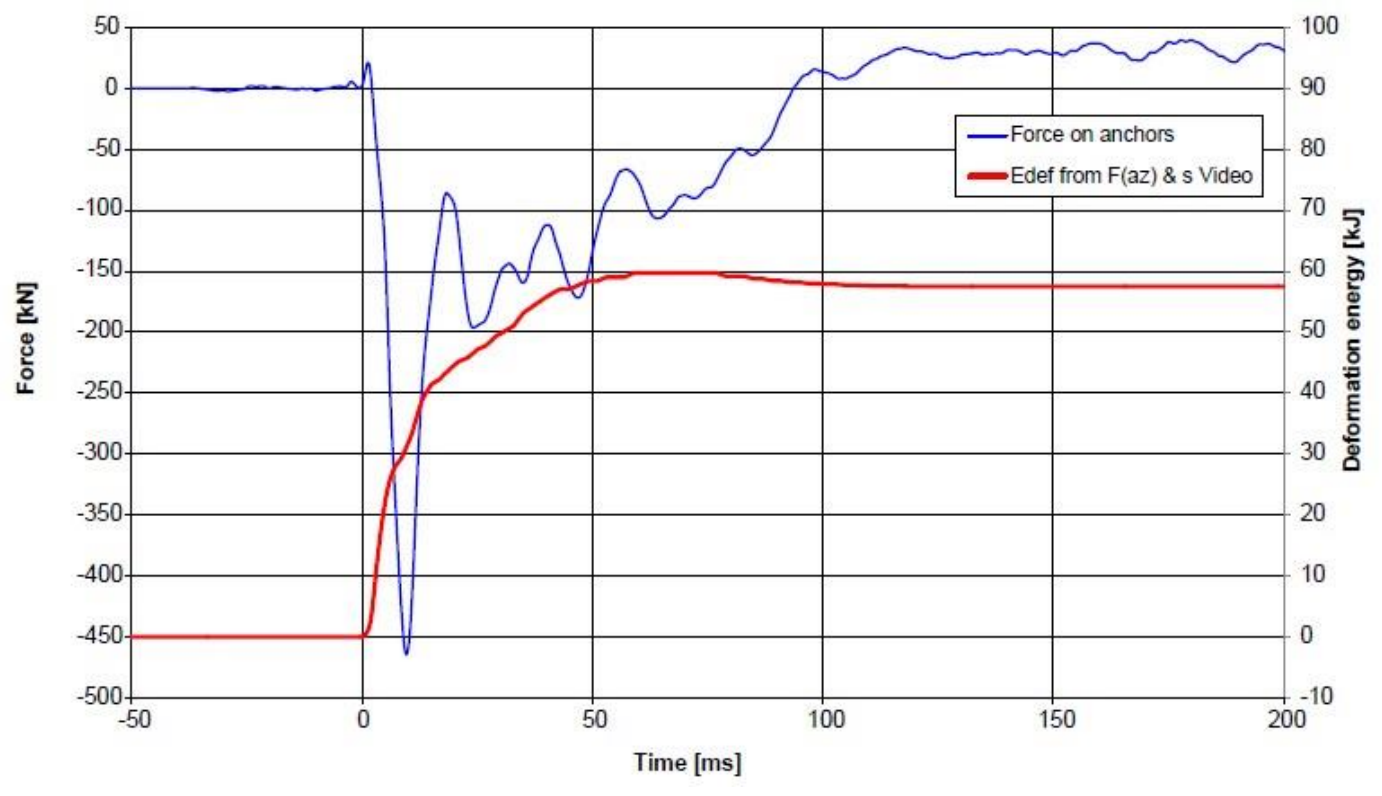

Figure 12 Test field S3 results. Sum of the forces in the load cell for anchors multiplied by two and maximum energy recorded 


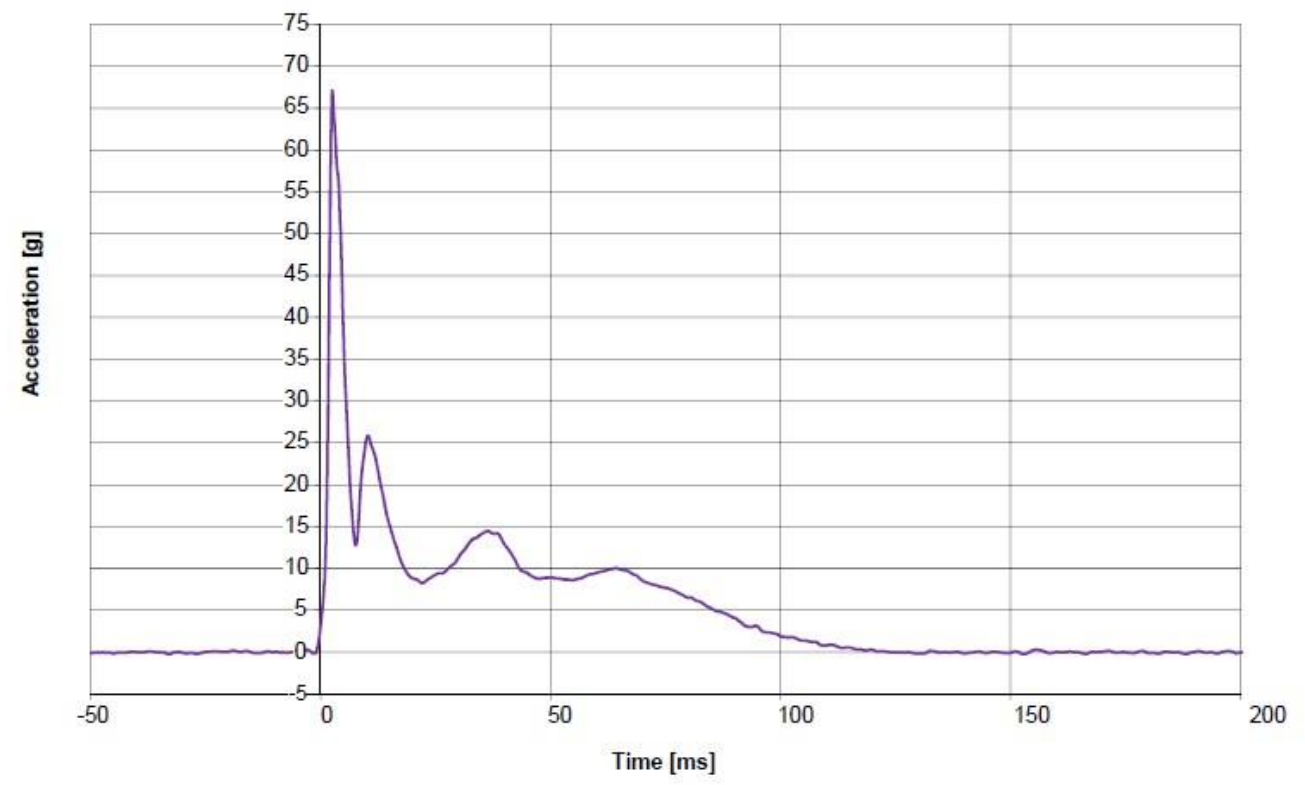

Figure 13 Test field S3 results. Acceleration on barrel at Z direction (filter CFC 180)

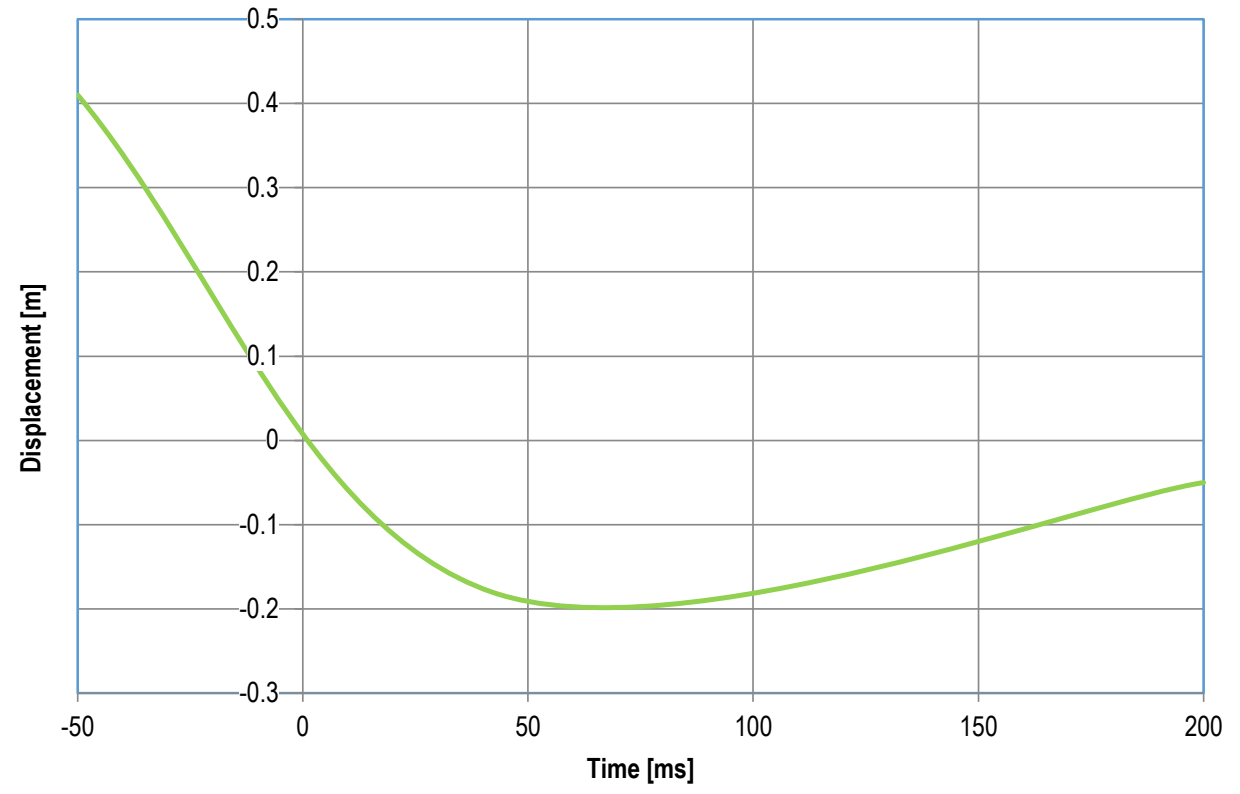

Figure 14 Test field S3 results. Maximum dynamic displacement $(0.24 \mathrm{~m}$ at $75 \mathrm{~ms})$

Figure 15 shows the consequences of the impact on the support system, with the effect of the rockburst simulation, seen from above and below. It can be seen that the surface support system remains largely intact with no mesh failure. After the $\mathrm{S} 3$ test, the composite shotcrete system had completely failed in the impact area. 


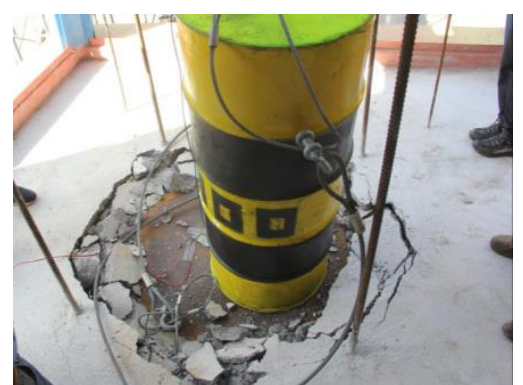

Impact point after test, top view

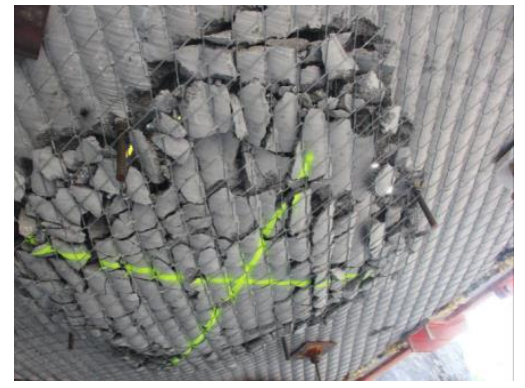

Impact point, bottom view

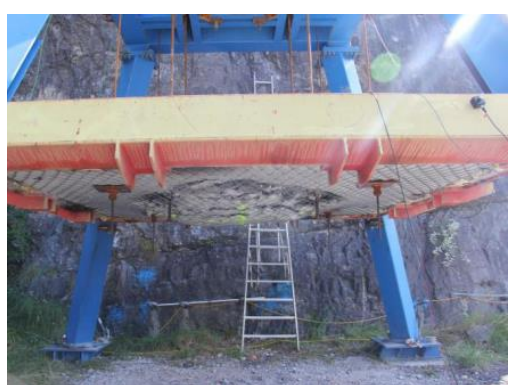

Frontal view of slab, bottom view

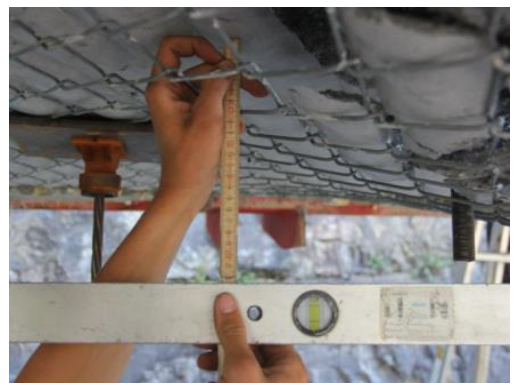

Static elongation of $0.225 \mathrm{~m}$

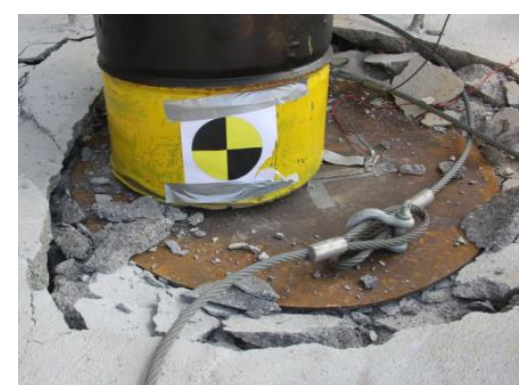

Steel plate not deformed, top view

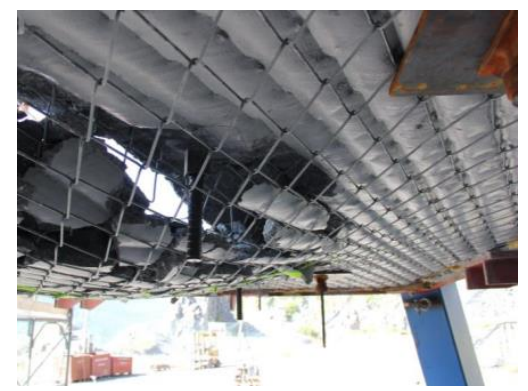

Detail of lower mesh MINAX $^{\circledR} 80 / 4$

Figure 15 Final set-up statuses after the first test S3

Once the S3 test was completed, the second impact, S4, was prepared on the same surface previously affected by the $\mathrm{S} 3$ test impact, so that the behaviour of the ground support system could be evaluated over an area affected by more than one consecutive event, without prior repair. The impact sequence for test S4 is described in Figure 16.

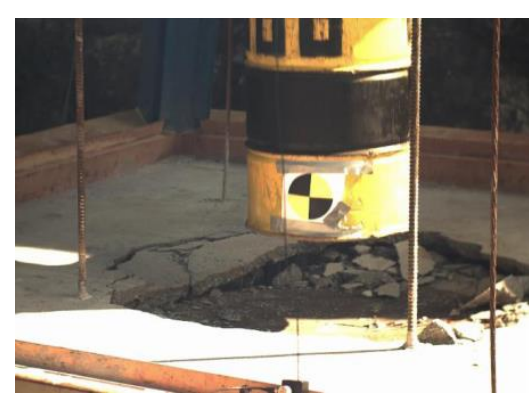

$\mathrm{t}=-50 \mathrm{~ms}$

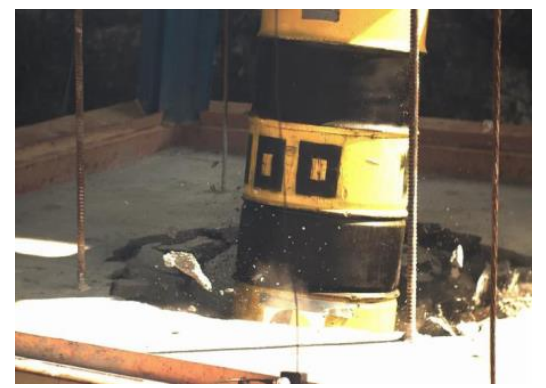

$\mathrm{t}=100 \mathrm{~ms}$

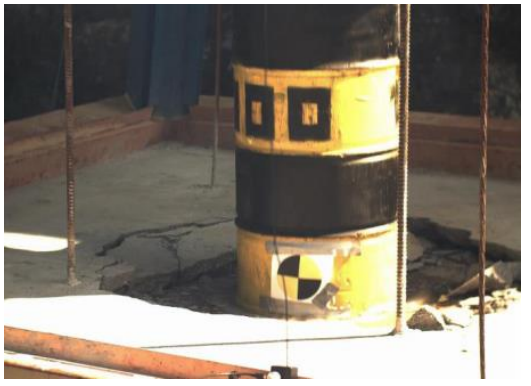

$\mathrm{t}=0 \mathrm{~ms}$

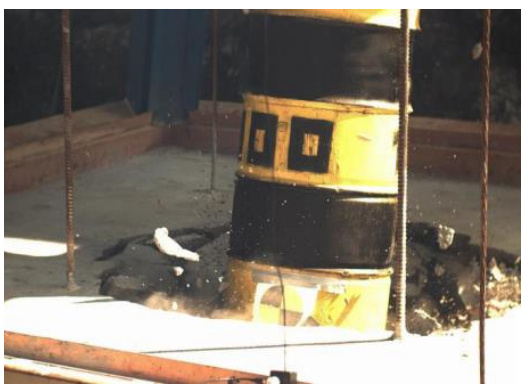

$\mathrm{t}=150 \mathrm{~ms}$

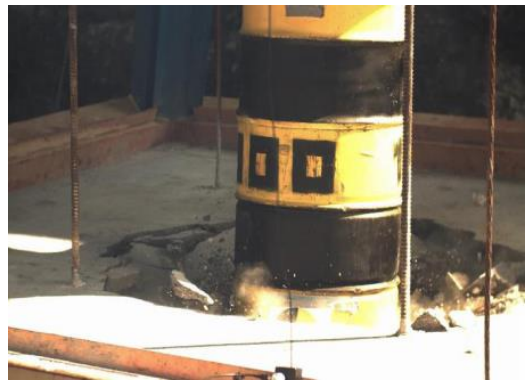

$\mathrm{t}=50 \mathrm{~ms}$

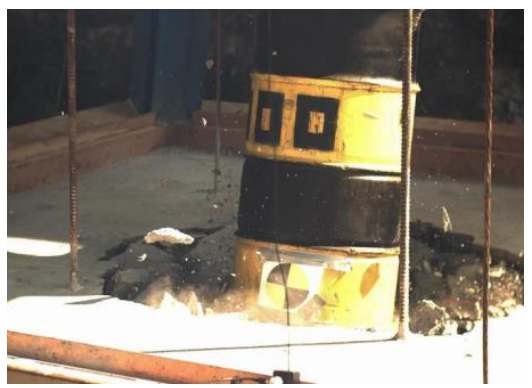

$\mathrm{t}=200 \mathrm{~ms}$

Figure 16 Impact sequence during test S4 with rebound from $100 \mathrm{~ms}$ 
In this test (Table 4), the release height was half of the previous $(2.30 \mathrm{~m})$ and the barrel weight was kept constant, thus the impact energy is about $30 \mathrm{~kJ}$. The system (previously impacted with $60 \mathrm{~kJ}$ ) was able to absorb an additional $30 \mathrm{~kJ}$ (Figure 17), and in this case the total amount of the forces into the anchoring system was $162 \mathrm{kN}$ and the maximum deceleration achieved was $33.4 \mathrm{~g}$ (Figure 18). This impact produced a dynamic central deflection of about $0.20 \mathrm{~m}$ (Figure 19).

Table 4 Summary S4 test results

\begin{tabular}{ll}
\hline Drop height & $2.30 \mathrm{~m}$ \\
Impact energy & $30 \mathrm{~kJ}$ \\
Max. anchor reaction & $162 \mathrm{kN}$ \\
Max. deceleration & $33.4 \mathrm{~g}$ \\
Max. central deflection & $0.20 \mathrm{~m}$ \\
Static deflection & $0.345 \mathrm{~m}$ \\
\hline
\end{tabular}

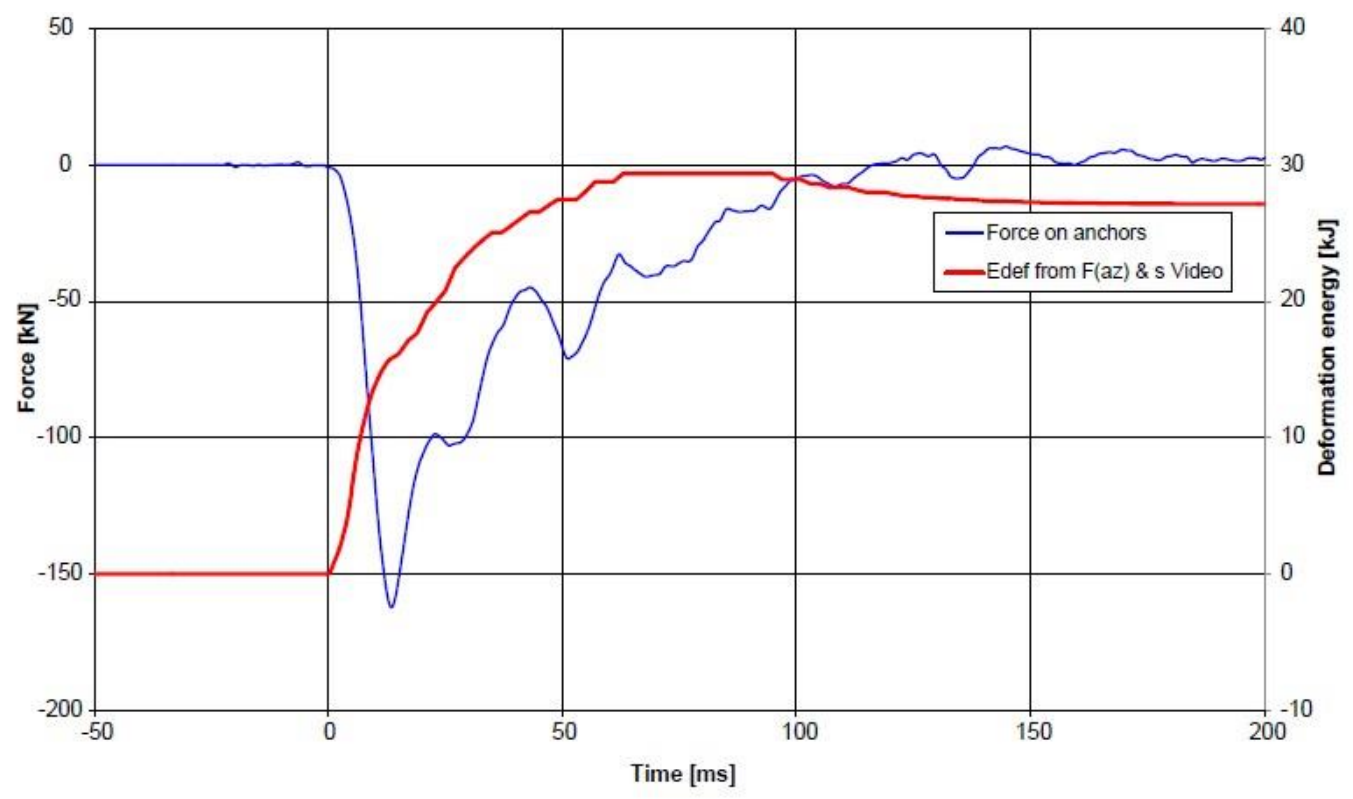

Figure 17 Test field S4 results. Sum of the forces in the load cell for anchors multiplied by two, and maximum energy recorded 


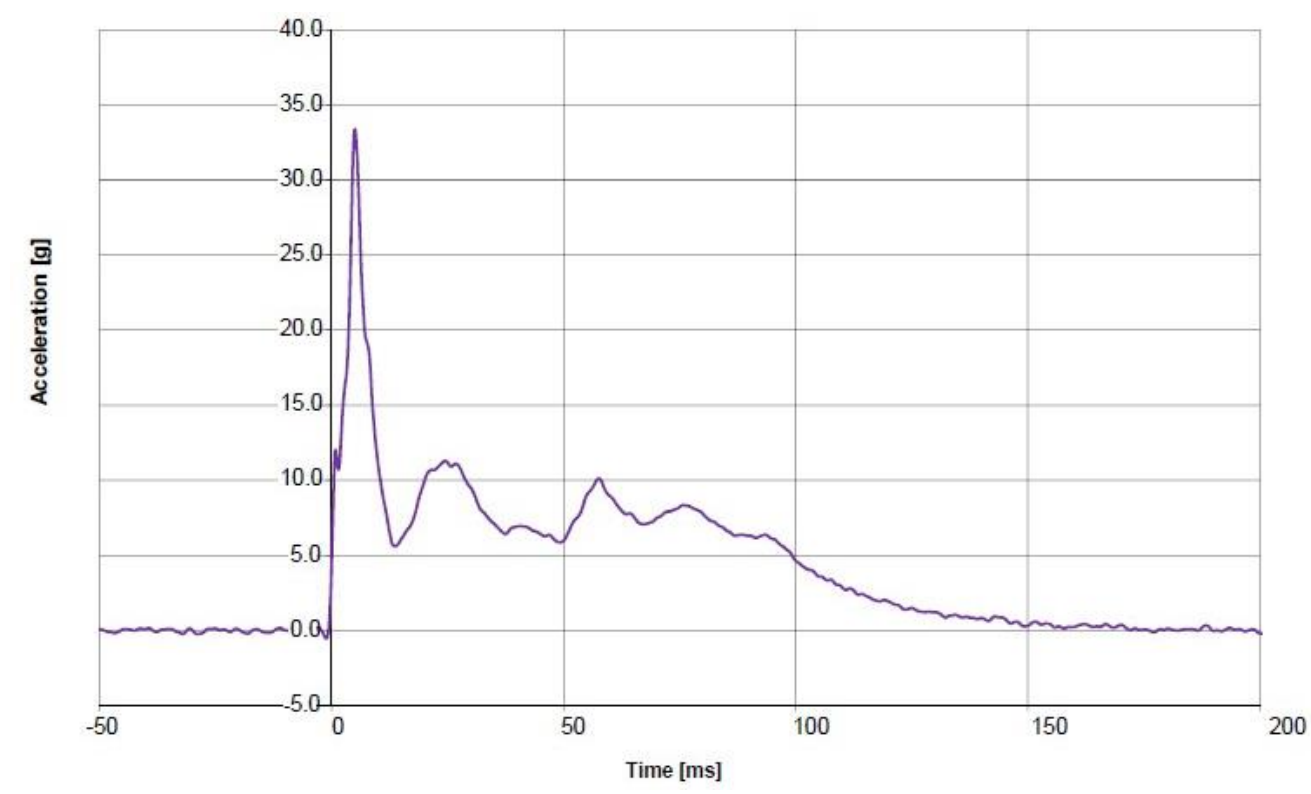

Figure 18 Test field S4 results. Acceleration on barrel at Z direction (filter CFC 180)

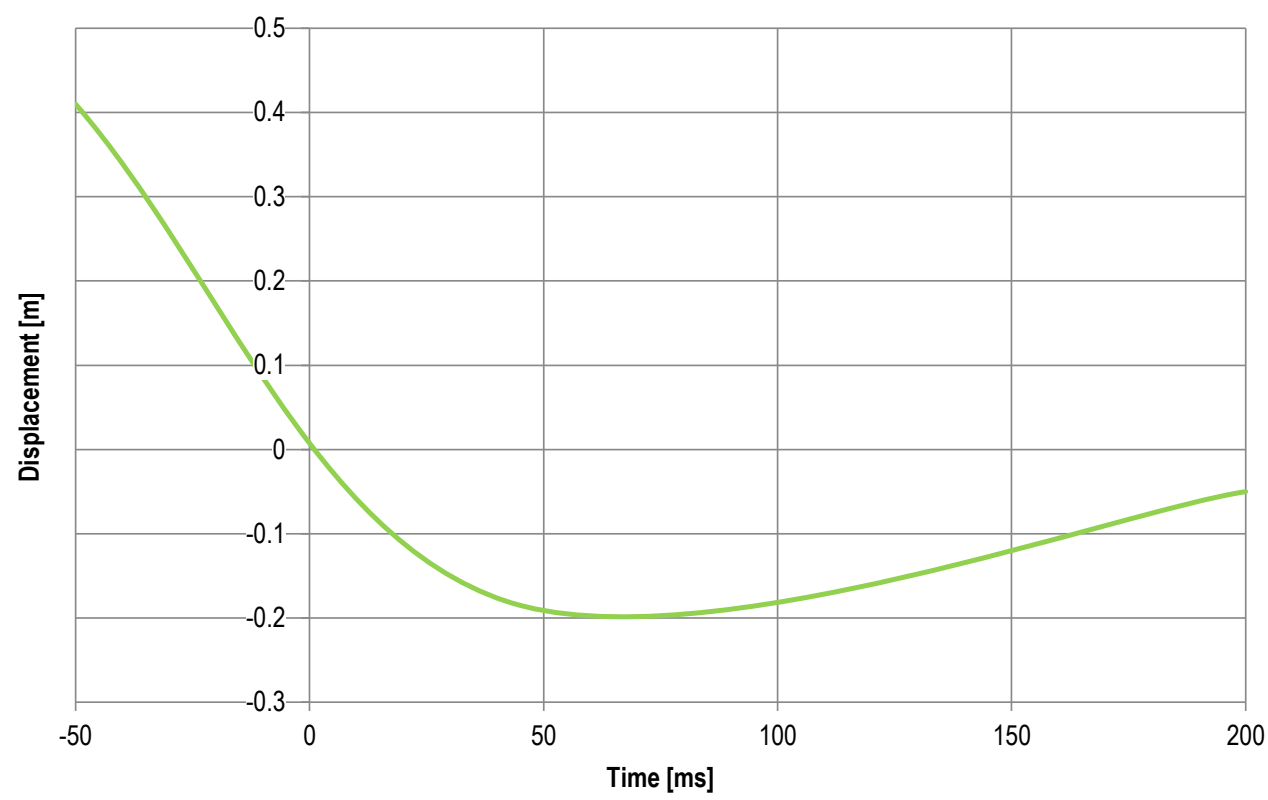

Figure 19 Test field S4 results. Maximum dynamic displacement $(0.20 \mathrm{~m})$ at $75 \mathrm{~ms}$

The results of the impact over the support system are shown in Figure 20, with the effect of the simulated rockburst seen from above and below. It can be seen that the mesh remained intact, but the composite shotcrete system failed. 


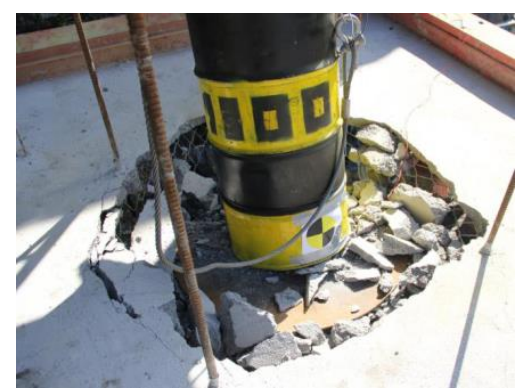

Impact point after test, top view

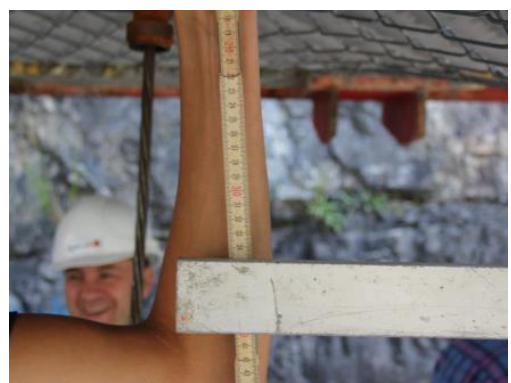

Static elongation of $0.345 \mathrm{~m}$

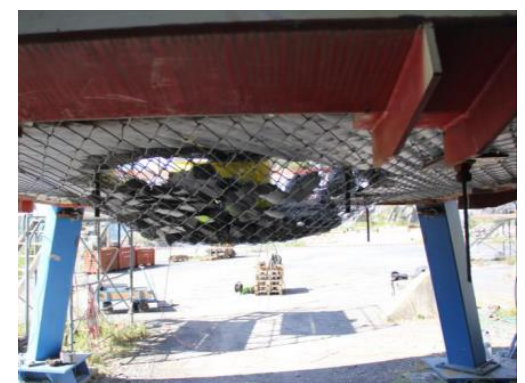

Impact point. Bottom view shotcrete has failed

Figure 20 Final set-up statuses after the second test, S4

The S5 test (last test performed, Figure 21) was also carried out on the same support system on which the two previous ones (S3 and S4) were carried out. No maintenance work on the steel meshes, shotcrete or the anchoring system was carried out prior to the test. The composite shotcrete layers present at the beginning were already non-existent, thus the majority of the impact force is transmitted to the anchoring system by the two layers of high-tensile wire mesh (with a $4 \mathrm{~mm}$ diameter and openings of 65 and $80 \mathrm{~mm}$ respectively).

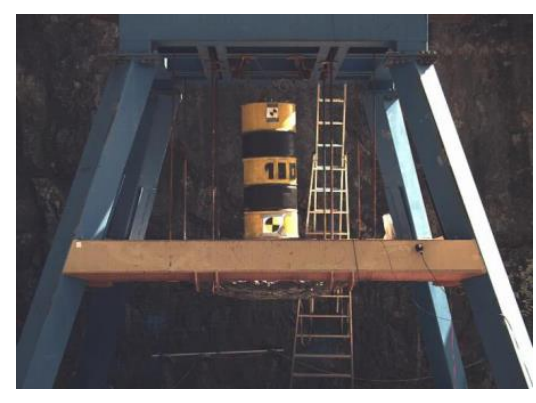

$\mathrm{t}=-50 \mathrm{~ms}$

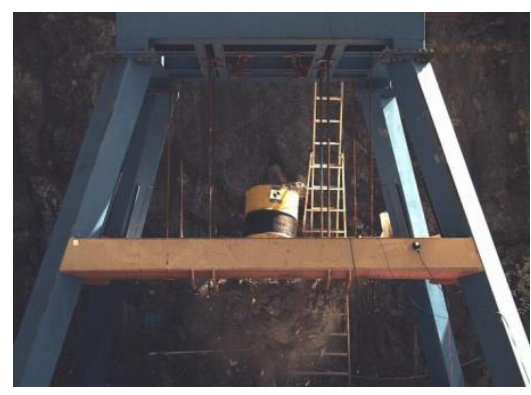

$\mathrm{t}=100 \mathrm{~ms}$

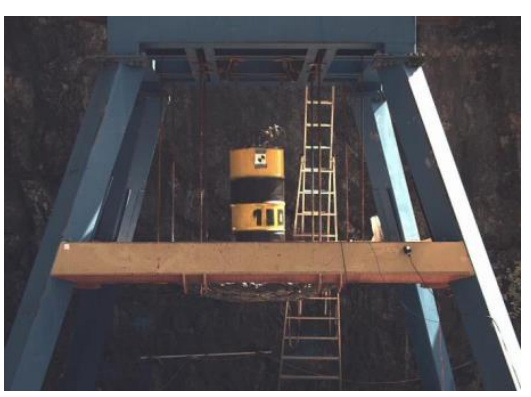

$\mathrm{t}=0 \mathrm{~ms}$

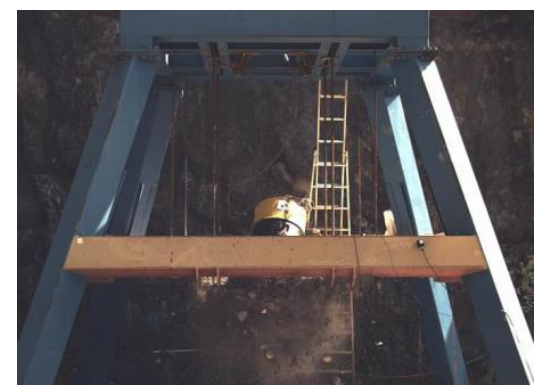

$\mathrm{t}=150 \mathrm{~ms}$

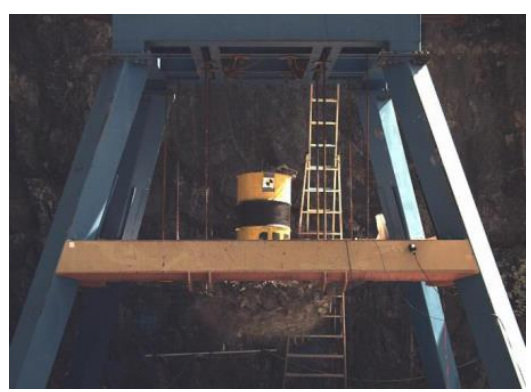

$\mathrm{t}=50 \mathrm{~ms}$

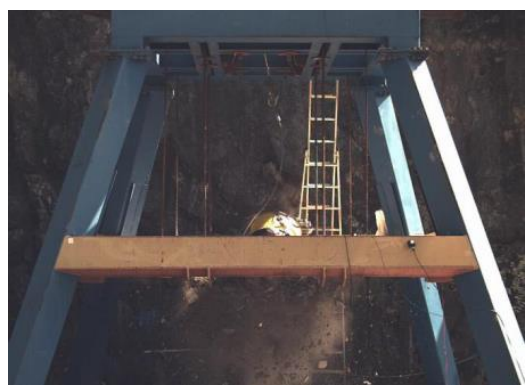

$\mathrm{t}=200 \mathrm{~ms}$

Figure 21 Impact sequence during test S5

In this case (Table 5) the release height was again the maximum $4.60 \mathrm{~m}$ and the barrel weight was equal, with the same impact energy to the S3 test at $60 \mathrm{~kJ}$. The system (previously impacted with 60 and $30 \mathrm{~kJ}$ ) now absorbed an additional $60 \mathrm{~kJ}$, with the total amount of the forces into the anchoring system being about $155 \mathrm{kN}$ (Figure 22), and the maximum deceleration corresponding to $32.5 \mathrm{~g}$ (Figure 23). This reduction can be attributed to the fact that the system stiffness has been reduced. The last impact induced a dynamic deflection of about $0.60 \mathrm{~m}$ (Figure 24). 
Table 5 Summary of S5 test results

\begin{tabular}{ll}
\hline Drop height & $4.60 \mathrm{~m}$ \\
Impact energy & $60 \mathrm{~kJ}$ \\
Max. anchor reaction & $155 \mathrm{kN}$ \\
Max. deceleration & $32.5 \mathrm{~g}$ \\
Max. central deflection & $0.60 \mathrm{~m}$ \\
Static deflection & Not measured \\
\hline
\end{tabular}

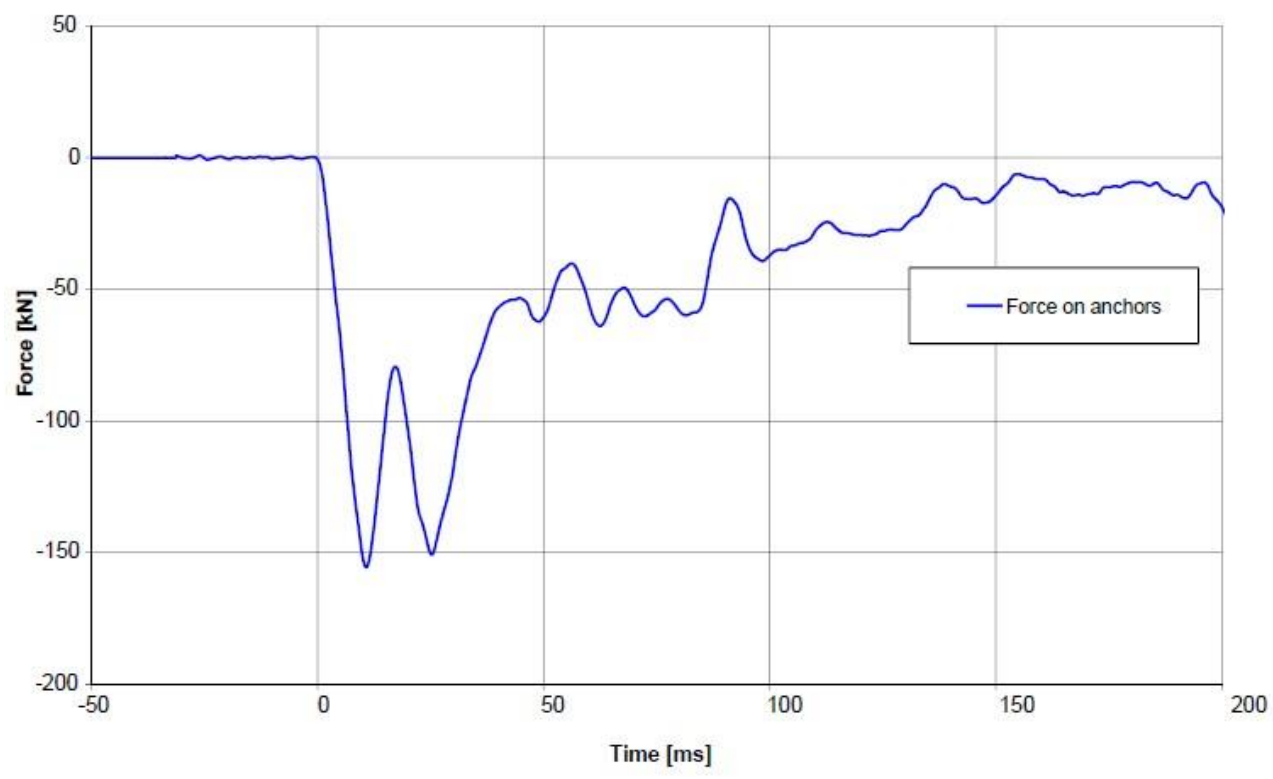

Figure 22 Test field S5 results. Sum of the forces in the load cells for anchors multiplied by two, and maximum energy recorded

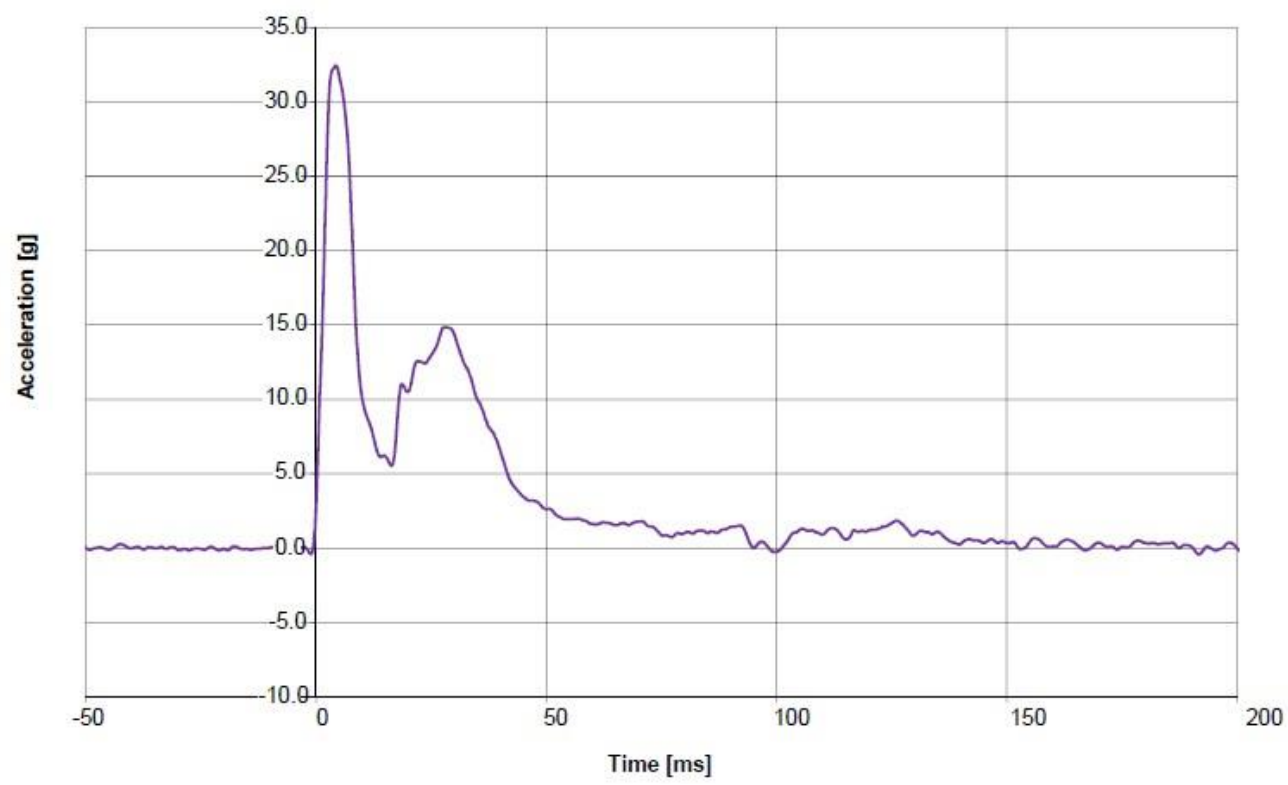

Figure 23 Test field S5 results. Acceleration on barrel at Z direction (filter CFC 180) 


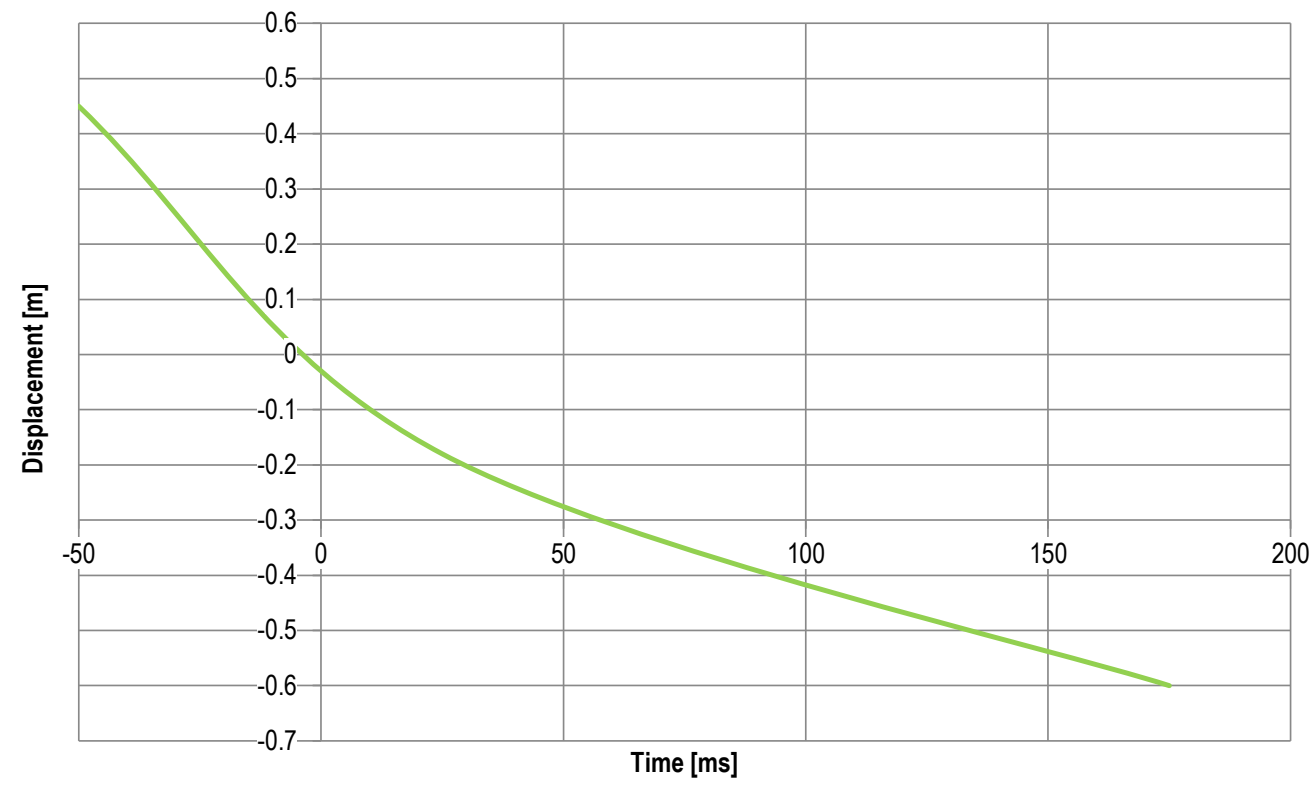

Figure 24 Test field S5 results. Maximum dynamic displacement $(0.60 \mathrm{~m})$

\subsection{Support system safety factor}

According to the force measurements in test S3, the maximum force values are generated in anchors 1 and 3 (Figure 25). These points correspond to the inner anchor system composed of $25 \mathrm{~mm}$ diameter 500-550 MPa steel bars. It can be seen that the maximum values observed in the test are in the order of $125 \mathrm{kN}$. If the anchor bars $\phi 25 \mathrm{~mm}$ are considered to have yield strength of $241 \mathrm{kN}$, the safety factor of the anchor system is 1.9 .

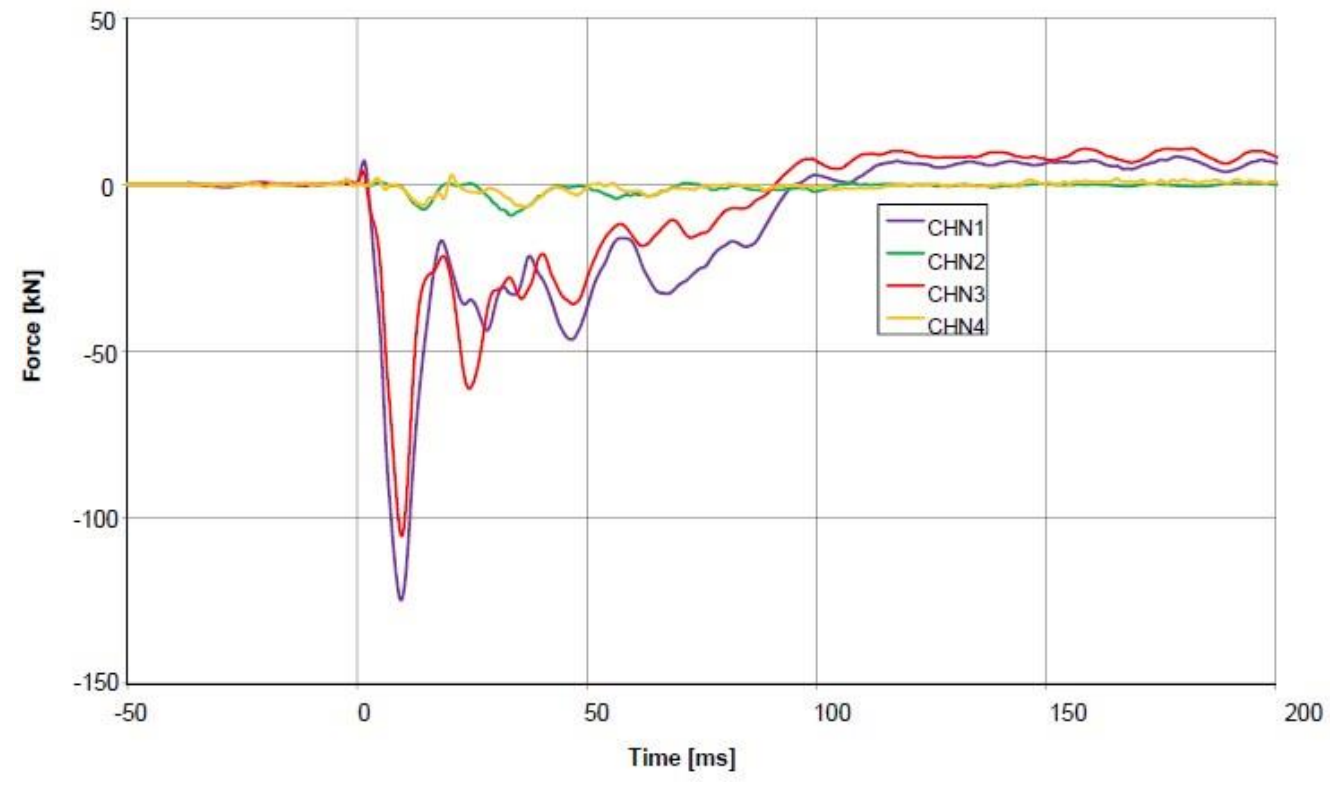

Figure 25 Test field S3 results. Anchor forces in Z direction (filter CFC 180)

In the following photos (Figure 26), it can be seen that the punching shear strength resistance is related to the number of wires involved, which are located all around the plate boundary section (red circles in Figure 26(b)) for the MINAX ${ }^{\circledR} 65 / 4$ mesh and the plate geometry load distribution. 


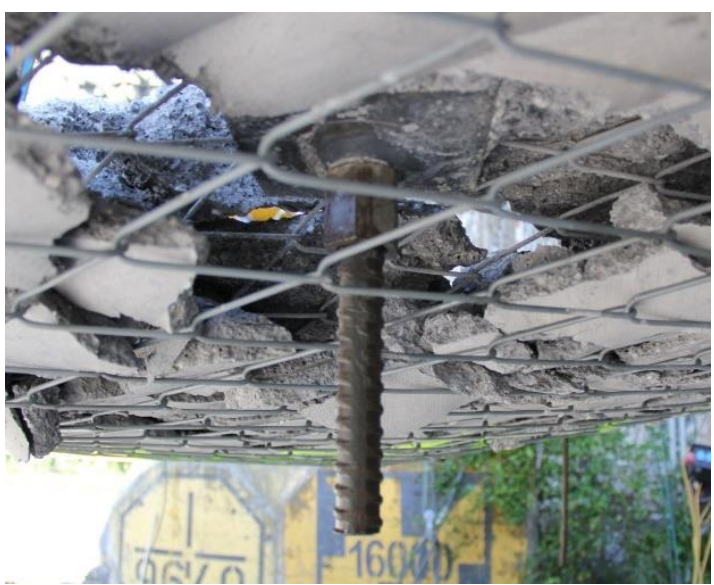

(a)

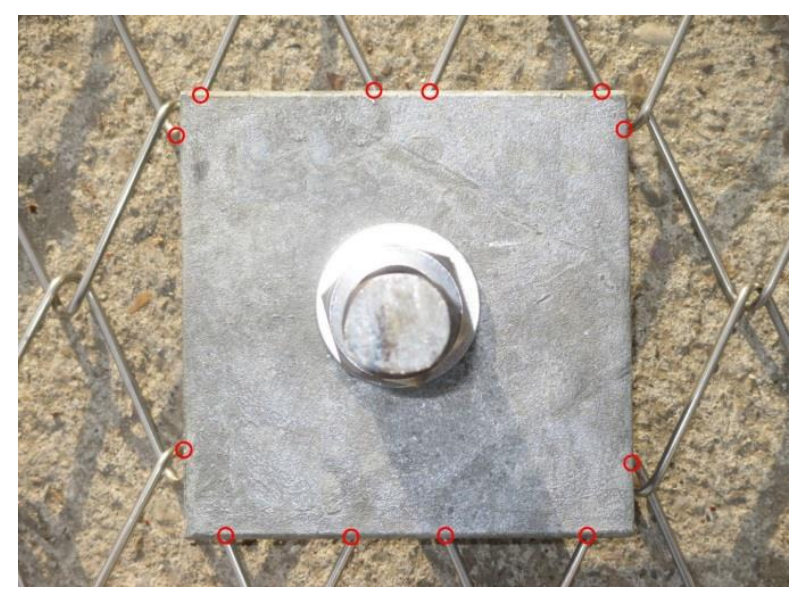

(b)

Figure 26 (a) Detail of the inner anchoring system at the end of the S3 test; and, (b) Number of wire contacts $(\mathrm{N}=12)$ for specific geometry

The theoretical shear force capacity (Equation 1) for the mesh with the distribution plate, neglecting the shotcrete influence, can be calculated with the number of wires, diameter and the tensile strength of the wire.

$$
\begin{gathered}
\tau_{\text {mesh MINAX® } 65 / 4-\mathrm{P} 15}=\mathrm{N} . \tau_{\text {wire } 4 \mathrm{~mm}} \\
\tau_{\text {wire } 4 \mathrm{~mm}}=0,577.2^{2} \cdot \pi \cdot 1,770=12.8 \mathrm{kN} \\
\tau_{\text {mesh MINAX }} 65 / 4 \text {-P15 } \\
=12 \cdot 12.8=154 \mathrm{kN}
\end{gathered}
$$

where:

$$
\begin{array}{ll}
\tau_{\text {mesh MINAX } 65 / 4-\mathrm{P}_{15}} & =\text { punching shear strength resistance. } \\
\mathrm{N} & =\text { number of contacted wires at the boundary of the plate. } \\
\tau_{\text {wire } 4 \mathrm{~mm}} & \text { shear resistance of the single wire } 4 \mathrm{~mm} \text { high yield strength. } \\
& \text { Safety factor }=154 / 125=1.23
\end{array}
$$

Additionally, the contribution of the MINAX ${ }^{\circledR} 80 / 4$ secondary mesh, in combination with the cable bolt, $140 \mathrm{~mm}^{2}$ (Figure 27), can also be evaluated. In the measurement channel corresponding with anchors 2 and 4 (Figure 25) maximum values observed in the test are in the order of $15 \mathrm{kN}$.

At the same time, the contribution in safety factor of this second part of the layer's combination can be estimated, neglecting the influence of the inner $\operatorname{MINAX}^{\circledast} 65 / 4$ mesh and the shotcrete.

$$
\tau_{\text {mesh MINAX }} 80 / 4-\mathrm{P} 20=16.12 .8=205.4 \mathrm{kN}
$$

As the average value of the maximum force measure for cable bolts at points 2 and 4 is $15 \mathrm{kN}$ in each one (Figure 25), much lower than the shearing resistance provided by the mesh, the full system safety factor is guaranteed for events such as those recorded in the impact tests at $60 \mathrm{~kJ}$. 


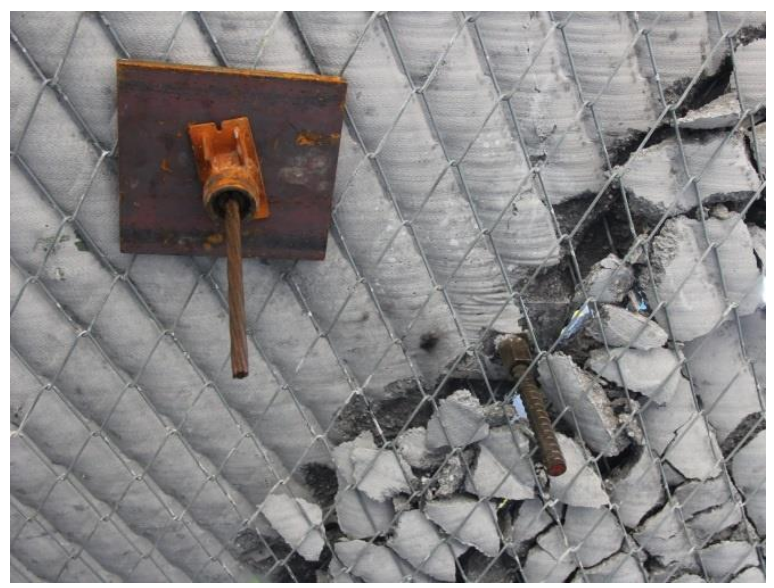

(a)

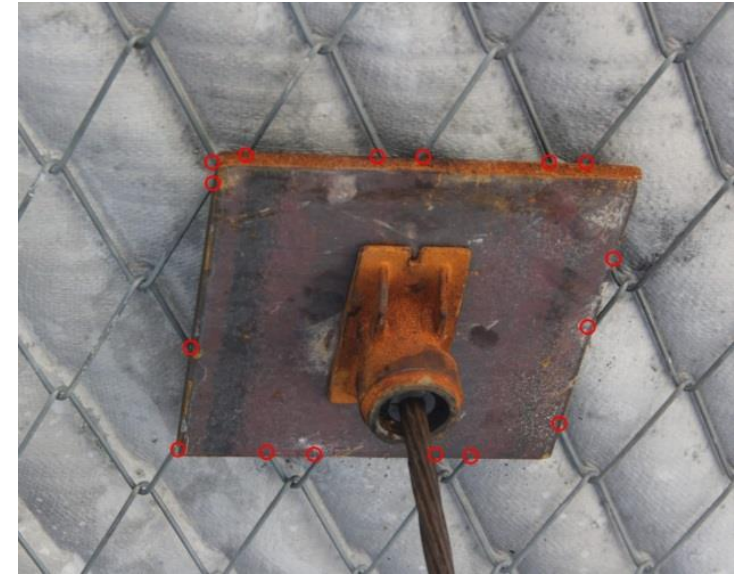

(b)

Figure 27 (a) Secondary layer MINAX® 80/4 with cable bolt remained unloaded at the end of the S3 test; and, (b) Number of wire contacts ( $N=16)$ for specific geometry

\section{Conclusion}

After successfully testing the high-tensile chain-link mesh under dynamic conditions, it was shown that this high-tensile mesh/shotcrete combination is suitable for ground support in areas with the potential for extreme rockburst. Dynamic laboratory tests contribute to the primary knowledge and establish initial parameters of comparison between different products. The series of large-scale tests allowed the verification of the dynamic ground support system for El Teniente mine. The elements of data acquisition (load sensors, accelerometers and high-speed video cameras) proved suitable. The detailed description of each of the tests allows quantification, measurement of the values of energy absorbed, and the determination of the correct distribution of the dynamic impact loads through the anchor system. The common test procedure, all on the same surface, allowed validation of the design. The results demonstrate that this type of design, with high-tensile chain-link mesh, allows high energy absorption of the dynamic loads from periodic rockbursts, without any maintenance requirement. This is fundamental for guaranteeing mine safety and contributing to the ultimate increase in productivity of mine development.

\section{References}

AOS Technologies AG 2017a, X-EMA high-speed camera, AOS Technologies AG, Baden Daettwil, viewed 5 July 2017, http://www.aostechnologies.com/high-speed-imaging/high-speed-cameras/x-ema/

AOS Technologies AG 2017b, X-PRI high-speed camera, AOS Technologies AG, Baden Daettwil, viewed 5 July 2017, http://www.aostechnologies.com/fileadmin/user_upload/PDFs/Legacy/X-PRI_Product_Leaflet_0708.pdf

Bucher, R, Cała, M, Zimmermann, A, Balg, C \& Roth, A 2013, 'Large scale field tests of high-tensile steel wire mesh in combination with dynamic rock bolts subjected to rock burst loading', in Y Potvin \& B Brady (eds), Proceedings of the Seventh International Symposium on Ground Support in Mining and Underground Construction, Australian Centre for Geomechanics, Perth, pp. 221-232.

Fischer, G 2016, 'Aplicación de recubrimiento flexible en excavaciones en minería a cielo abierto y subterráneas', presentation at the 2 o Congreso Internacional de Minería y Geología, 25 November 2016, Panama City.

Gutierrez, G 2002, High-tensile Wires Mesh Characterization, Laboratory Report, University of Cantabria. Santander.

Luis Fonseca, R, Laguna, L \& Muñoz, B 2009, 'Comparative analysis of the mechanical properties of the steel membranes for slope stabilization', VII National Symposium on Unstable Hills and Slopes, Barcelona, Spain.

Morton, E, Thompson, A, Villaescusa, E \& Roth, A 2007, 'Testing and analysis of steel wire mesh for mining applications of rock surface support', in C Olalla, N Grossman \& L Ribeiro e Sousa (eds), Proceedings of the 11th Congress of the International Society for Rock Mechanics, Taylor \& Francis, London, pp. 1061-1064.

Muñoz, A 2017, 'Metodología para la incorporación de nuevos elementos de fortificación en División El Teniente', Diploma in Geomechanics Applied to Mining Design, University of Chile, Santiago.

Player, JR, Morton, E, Thompson, A \& Villaescusa, E 2008, 'Static and dynamic testing of steel wire mesh for mining applications of rock surface support', Proceedings of The Sixth International Symposium on Ground Support in Mining and Civil Engineering Construction, The South African Institute of Mining and Metallurgy, Johannesburg, pp. 693-706. 
Player, JR, Villaescusa, E \& Thompson AG 2004, 'Dynamic testing of rock reinforcement using the momentum transfer concept', in E Villaescusa \& Y Potvin (eds), Proceedings of the Fifth International Symposium on Ground Support in Mining and Underground Construction, A.A Balkema, Rotterdam, pp. 327-339.

Roduner, A 2012, Salt Spray Test Certificates, Geobrugg, Romanshorn.

Roth, A 2013, Testing and Numerical Modelling of High-tensile Steel Wire Mesh for Ground Support under Dynamic Loading, MSc thesis, Western Australian School of Mines, Curtin University, pp. 24-64.

Roth, A, Windsor, C, Coxon, J \& de Vries, R 2004, 'Performance assessment of high-tensile steel wire mesh for ground support under seismic conditions', in E Villaescusa \& Y Potvin (eds), Proceedings of the Fifth International Symposium on Ground Support in Mining and Underground Construction, A.A. Balkema, Rotterdam, pp. 589-594.

Saner, A \& Murri R 2016, Testing of the Rockburst Codelco Setup S3-S5, Report No. Psi-16-1231, Dynamic Test Center AG, Vauffelin/Biel, Switzerland.

Thompson, A, Player, J \& Villaescusa, E 2004 'Simulation and analysis of dynamically loaded reinforcement systems', in E Villaescusa \& Y Potvin (eds), Proceedings of the Fifth International Symposium on Ground Support in Mining and Underground Construction, A.A. Balkema, Rotterdam, pp. 341-355.

Villaescusa, E, Azua, J, Player, J, Thompson, A \& Morton, E 2012, 'A database of static and dynamic energy absorption of mesh for rock support', CRC Mining, Western Australian School of Mines, Curtin University, Perth, pp. 1-8. 
